\title{
24. Feminist okuma ekseninin yazın çevirisine izdüşümleri: Orhan Pamuk'un Veba Geceleri örneği
}

Mesut KULELI'1

APA: Kuleli, M. (2021) Feminist okuma ekseninin yazın çevirisine izdüşümleri: Orhan Pamuk'un Veba Geceleri örneği. RumeliDE Dil ve Edebiyat Araştırmaları Dergisi, (0̈9), 284-306. D0I: 10.29000/rumelide.984772.

$\ddot{0} \mathbf{z}$

Bu çalışmanın amacı, Orhan Pamuk'un 2021 Mart'ta Türk edebiyat çoğuldizgesine giren Veba Geceleri başlıklı romanını toplumsal cinsiyet inşasına dayalı feminizm kuramı çerçevesinde çözümleyerek romanın gelecekte Batı dillerine yapılması beklenen çevirileri için romanın çoğul okuma eksenlerinden feminist okumaya dayalı zorlukları göstermektir. Roman, kurgusal Minger Adası üzerinden ve Padişah V. Murat'ın (kurgusal) kızı Pakize Sultan karakterinin bu adada geçen olayları ablası Hatice Sultan'a yazdığı mektuplara dayandırılarak bir tarihsel roman olarak okunabilmesinin yanı sıra yazarın giriș bölümünde öncelediği gibi feminist okumaya açıktır. Toplumsal cinsiyet inşasına dayalı feminist kuram, cinsiyet ve rollerinin biyolojik ve doğa gereği oluşan olgular olmadığını, toplumların ataerkil yapılarının ürettiği ve dünyaya gelen her bireyin içinde yaşadığı toplumsal değerler çerçevesinde bu cinsiyet rollerini öğrendiğini öne sürmektedir. Hem toplumsal hayatta hem de iş dünyasında inşa edilen kadın erkek eşitsizliğinin ataerkil toplum tarafından yeniden üretildiğini öne süren bu feminist kurama göre, toplumsal bir süreç olan cinsiyet rollerinin inşası aynı zamanda güç ve toplumsal kontrol sahibini de bu yolla belirlemektedir. İncelenen romanda kadınların sadece ev işleri ve çocuk bakımı ile kısıtlandığı, romanda geçen tüm mesleklerin sadece erkekler tarafından yapılmakta olduğu ve yegane güç sahibinin erkek olduğu görülmektedir. Romandaki tüm erkek karakterler meslekleri veya sahip oldukları sosyal statü ile adlandırılırken tüm kadın karakterler kimin kızı veya eşi olduğu söylenerek okura tanıtılmıştır. Kadınların evlilikleri ve alacakları sağlık hizmeti de ataerkil normlarla belirlenmiştir. Toplumsal olarak inşa edilmiş cinsiyet rollerinin romandaki dili de etkilediği, cinsiyet belirtilmeyen rollerde "adamlar" veya "baba", "dede" gibi eril göstergelerin kullanıldığı bulunmuştur. Bu çalışmada, Türkçeden diğer dillere en çok çevrilen yazarlardan olan Orhan Pamuk'un bu romanının da Batı dillerine yapılması beklenen çevirilerinde yazın çevirmeninin ve editörlerin romanı feminist okuma ile çözümlemesinin, romandaki dil kullanımında yaşanabilecek anlam dönüşümlerini ve anlam kayıplarını en aza indirebileceği özgül söylemler ile tartışılmaktadır.

Anahtar kelimeler: Feminist kuram, toplumsal cinsiyet, yazınsal çeviri, çoğul okuma eksenleri, yazınsal feminizm

\section{Projections of feminist reading to literary translation: The Case of Veba Geceleri (Nights of Plague) by Orhan Pamuk}

\author{
Abstract \\ The aim of this study is to analyze the novel titled Veba Geceleri (Nights of Plague) by Orhan Pamuk, \\ which was introduced to the Turkish literary polysystem in March 2021, within the framework of \\ feminist theory based on gender construction, and to show the difficulties based on feminist reading \\ 1 Doç. Dr., Bolu Abant İzzet Baysal Üniversitesi, Yabancı Diller Yüksekokulu, Mütercim ve Tercümanlık Bölümü, İngilizce \\ Mütercim ve Tercümanlık ABD (Bolu, Türkiye), mesut.kuleli@ibu.edu.tr, ORCID ID: 0000-0002-3477-0412 ([Araştırma \\ makalesi, Makale kayıt tarihi: 26.07.2021-kabul tarihi: 20.08.2021; DOI: 10.29000/rumelide.984772] \\ Adres | Address \\ RumeliDE Dil ve Edebiyat Araştırmaları Dergisi $\quad$ RumeliDE Journal of Language and Literature Studies \\ Osmanağa Mahallesi, Mürver Çiçeği Sokak, No:14/8 $\quad$ Osmanağa Mahallesi, Mürver Çiçeği Sokak, No:14/8 \\ Kadıköy - İSTANBUL / TÜRKIYE 34714 Kadıköy - ISTANBUL / TURKEY 34714 \\ e-posta: editor@rumelide.com $\quad$ e-mail: editor@rumelide.com \\ tel: +90 505 7958124, +90 2167730616 phone: +90 505 7958124, +90 2167730616
}


from the plurality of reading axes of the novel for potential translations expected to be made into Western languages in the future. The novel can be read as a historical novel set in the fictional Minger Island plotted around the letters the (fictional) character Pakize Sultan, Sultan Murat V's daughter, wrote to her elder sister Hatice Sultan. The novel also lends itself to a feminist reading as openly stated by the author in the Introduction part of the novel. Social construction feminism argues that the making of gender and gender roles are not natural and biological phenomena, but that each individual born into the world learns these gender roles within the framework of the social values they live in. According to social construction feminism, which argues that the inequality between women and men, constructed both in social life and in the business world, is reproduced by patriarchal society, whereby determining the party in power and social control. A feminist reading of the novel shows that women are restricted to housework and childcare, with all occupations performed only by men, and the sole power holder is men. While all male characters in the novel are introduced to the reader based on their profession or social status, all female characters are introduced by saying whose daughter or wife they are, showing female characters as dependent beings. The marriage of women and the health services they will receive are also found to be determined by patriarchal norms. It is further found that socially constructed gender roles also affect the use of language in the novel, and masculine signs such as "men" or "father", "grandfather" are used in roles that do not specify the gender. In this study, it is recommended with references to specific contexts from the novel that the literary translators and editors analyze the novel through feminist reading prior to the translations of this novel, expected to be made into Western languages in the near future in order to minimize the meaning transformations and loss of meaning that might occur in the use of language in the novel. Besides, certain recommendations for literary feminist theory are also put forward to determine translators' skopos and deconstruct the patriarchal society in translations of literary texts.

Keywords: Feminist theory, gender, literary translation, multiple readings, literary feminism

\section{Giriş: Toplumsal cinsiyet inşasına dayalı feminizm}

Toplumsal cinsiyet, bireyin doğumunda doğanın sunduğu biyolojik cinsiyet üzerine temellenen ancak doğanın sunduğunun çok ötesinde bireye toplumsal yaşam içerisinde atfedilen rollerden oluşmaktadır. Bireyin dünyaya geldiği andan itibaren ona verilen ad, giydirilen klyafetler, bu klyafetlerin renkleri, küçüklüğünde oynaması uygun görülen oyuncaklar, erişkinlik döneminde takınması gereken tutum ve tavırlar, evlilik dönemi ve sonrasında kullanacağı soyadı ve ev içinde yapılacak işler, meslek hayatında seçeceği sektörler ve iş pozisyonları gibi hemen her adımını belirleyen koşullar, kişinin içine doğduğu toplumun oluşturduğu ve nesilden nesile bu değerlerini aktardığı “yapay” durumlardır. Lorber’a (1991, s. 112) göre, "[doğumdaki] biyolojik cinsiyet, verilen ad, kıyafetler ve diğer göstergeler ile toplumsal cinsiyete dönüşür" 2. Bireylerin toplumsallaşma süreçlerini yöneten ve yönlendiren tüm şartlar, bu toplumsal cinsiyet modeli ile belirlenmektedir.

Genel bir toplumsal inşa koşulu olan kız çocukların pembe kıyafetler erkek çocukların ise mavi kıyafetler giymesi gerektiği; mutfağın ve temizlik işlerinin kadının biyolojisine uygun olup erkek biyolojisine ters olduğu; yönetim pozisyonları veya fiziksel güç gerektiren mesleklerin erkeklere daha uygun olduğu gibi varsayımlara dair herhangi bir bilimsel dayanak bulunmamakla birlikte tüm bu toplumsal cinsiyet rolleri kadınları zayıf, güçsüz, daha duygusal, daha temkinli olması gereken ve öteki konumunda, erkekleri ise fiziksel ve mental olarak güçlü, yöneticiliğe uygun, duygularını göstermemesi, aynı zamanda kadını koruması ve kollaması beklenen bireyler olarak göstermektedir. Bu durum, ataerkil bir toplum yapısının

2 Aksi belirtilmedikçe çeviriler tarafımıza aittir.

RumeliDE Dil ve Edebiyat Araştırmaları Dergisi Osmanağa Mahallesi, Mürver Çiçeği Sokak, No:14/8 Kadıköy - ISTANBUL / TÜRKIYE 34714 e-posta: editor@rumelide.com tel: +90 $5057958124,+902167730616$
Address

RumeliDE Journal of Language and Literature Studies

Osmanağa Mahallesi, Mürver Çiçeği Sokak, No:14/8

Kadıköy - ISTANBUL / TURKEY 34714

e-mail: editor@rumelide.com

phone: +90 5057958124, +90 2167730616 
Projections of feminist reading to literary translation: The Case of Veba Geceleri (Nights of Plague) by Orhan Pamuk / M. Kuleli (pp. 284-306)

ezelden beri süregelmesine ve doğduğu zamandan itibaren bireylerin zihinlerine kazınmasına, böylece ataerkil yapının normal olan toplum yapısı olarak görünmesine yol açmışırı. Böylece cinsiyetler arasındaki eşitsizlik, doğanın sunduğu biyolojik bir olgudan kaynaklanmamaktadır; toplumların kültürlerinde inşa ettikleri hiyerarşik bir düzensizlik olarak karşımıza çıkmaktadır.

Ataerkil toplumun "düzen" diye empoze ettiği durum, kadınların ötekileştirilmesine ve baskı altında yaşamasına neden olması nedeniyle bu çalışmada düzensizlik olarak ele alınmaktadır. Toplumun işleyişi ve kendi değerlerini sürdürebilmesi için bireylerin huzur, güven ve adalet duygusuyla yaşadığı bir toplum modelini "düzen" şeklinde tanımlamak mümkün olabilirken, günümüzde batıdan doğuya tüm gelişmiş ve gelişmekte olan toplumlarda bu tanımda yer alan "adalet" duygusu, erkekler lehine işlemekte ve kadınların ayrımcılıktan etkilenen baskı altındaki bireyler olması nedeniyle eksik kalmaktadır. Bu durum, toplumda bir düzenden öte bir düzensizlik, bir grubun sadece sahip olduğu biyolojik cinsiyete bakarak onlara toplumsal olarak biçilmiş roller yoluyla ötekileștirilmesi ile sonuçlanmaktadır. Ancak toplumun ataerkil yapısını sürdürme isteği, bazı kesimler tarafından eleştirel olarak yaklaşıımış ve düzensizliğin gerek düzene dönüşmesi için çeşitli feminist akımlar belirmiştir. Tüm feminist akımlar, toplumsal olarak inşa edilmiş kategorileri yok etmeye, cinsiyet başta olmak üzere ırk, din, eğitim seviyesi, toplumsal statü, ekonomik durum gibi her türlü hiyerarşik sınıflandırmayı sona erdirmeye, sadece ikiliklerden oluşan toplumsal öngörülere çoğulluk bakışı kazandırmaya yönelik uğraşlar verirken ortaya çıktı̆̆ı dönem, yöntem ve karşı oldukları eşitsizliğin çıkış noktası bakımından birbirlerinden farklılıklar barındırmaktadır. Bu çalışmada, eșitsizliğin merkezinde cinsiyeti gören "toplumsal cinsiyet inşasına dayalı feminist kuram" temel alınmıştır. Lorber (1997, s. 25) bu feminist kuramı, egemen toplumsal yapıdaki sınıflandırmaların belirsizliğini tartışması ve erkeklere egemen rolü veren iç içe geçmiş imtiyaz ve güç yapılarını yapısöküme uğratması bakımından "cinsiyet devrimi feminizmleri" içinde sınıflandırmıştır.

[Toplumsal cinsiyet inşasına dayanan feminizm] cinsiyeti toplumun tüm örgütlerinin içine işlemiş bir kurum olarak görmektedir. Toplumsal bir kurum olarak cinsiyet, güç, imtiyaz ve ekonomik kaynakların dağılımını belirleyen unsurdur. Toplumsal cinsiyet normları ve beklentileri, kadın ve erkeklerin benlik algısını etkilemekte; bu normlardan ve beklentilerden farklı bir șekilde davranmak veya iş ve aile hayatını düzenlemek deyim yerindeyse kabul edilemez durumlardır. (Lorber, 1997, s. 29).

$\mathrm{Bu}$ önermede görülebileceği üzere bireyin nasıl davranacağını, ne kadar ekonomik güce ve bağımsızlığa sahip olacağını, toplumda egemen veya ezilen konumunda olması gerektiğini, alabileceği iş pozisyonları ve aile hayatında yapacağı görevleri belirleyen yegane faktör cinsiyettir. Bunun sonucunda bireyler arasında ortaya çıkan ayrımcılık, egemen toplum yapısı olan ataerkil toplumsal değerler nedeniyle kadınlara, erkeklere nazaran büyük dezavantajlar getirmektedir. Diğer bir deyişle, eğitim, iş dünyası, ekonomik güç, aile ilişkileri gibi etrafımızı saran koşullarda kadın hep ezilen, erkek hep egemen konumda inşa edilmiştir. $\mathrm{Bu}$ toplumsal inşa, bazı bilimsel veya toplumsal uğraşlarla da ataerkil toplum tarafından güvence altına alınmaktadır. "Toplumun gerektirdiği cinsiyet rollerini sergilemeyen bireyler, çeşitli tıp alanları tarafından 'hasta', dini terimlerle 'günahkar' veya hukuki olarak 'suçlu' olarak görülmektedirler" (Lorber, 1997, s. 30). Tüm bu ötekileştirici hiyerarşik göstergelere karşı çıkan toplumsal cinsiyet inşasına dayalı feminist kuram, biyolojik cinsiyeti de iki zıt kutuptan kurtarmaya, biyolojik cinsiyetin çoğulluğuna vurgu yapmaya, cinsiyet değiștirmenin bireyin toplumdaki statüsünü de değiștirmesi anlamına gelmemesi gerektiğine odaklanır. Ancak "açık bir meydan okuma olmaksızın toplumsal cinsiyet inşası temelli örgütlenmenin değişmesi pek olası gözükmemektedir" (Lorber, 1997, s. 31). Cinsiyet eşitliğine dayalı hiyerarşisiz bir topluma geçiş bir anda olabilecek bir surum olmasa da hem bireysel düzeyde hem de toplumsal düzeyde bilinç uyandırılması ile bu amaç kademeli olarak gerçekleşebilmelidir.

Adres

RumeliDE Dil ve Edebiyat Araştırmaları Dergisi Osmanağa Mahallesi, Mürver Çiçeği Sokak, No:14/8 Kadıköy - ÍSTANBUL / TÜRKIYE 34714 e-posta: editor@rumelide.com tel: +90 505 7958124, +902167730616
Address

RumeliDE Journal of Language and Literature Studies

Osmanağa Mahallesi, Mürver Çiçeği Sokak, No:14/8

Kadıköy - ISTANBUL / TURKEY 34714

e-mail: editor@rumelide.com

phone: +90 5057958124, +90 2167730616 
Tüm toplumsal olgular gibi toplumsal cinsiyet de edebiyata yansımıştır. Yazılı veya sözlü, her toplumun edebiyatında o dönemin veya eski dönemlerin kadın ve erkek rolleri metinlerin derin anlamında yerlerini bulmuştur. Her metin türünde, kadın ve erkeklerin görev veya hakları toplumun inşa ettiği bağlamda sunulmuştur. XI. yüzyıl ve XVIII. yüzyıla ait iki Türk edebiyatı metnini XII. ve XVI. yüzyıllara ait iki Rus edebi metni ile karşılaştırmalı olarak çözümleyen Tetik (2020, s. 116), "[s]öz konusu eserlerin ortak paydası[nın], toplumsal gücün erkeğe ait olduğu ataerkil toplum düzeninin etkisinde yazılmış olduğu[nu] [ve] bunun sonucunda eserlerde, cinsiyete dayalı hiyerarşi, erkeği kadın karşısında üstün tutan, kadını ise birey olarak görmeyen, ikincilleştiren ve ötekileştiren bir yaklaşım” olduğunu öne sürmektedir. Ayrıca Tetik (2020), arada geçen yüzyıllara rağmen her iki toplumda da kadın öteki, erkeğin ise egemen konumunun değişmediğini ifade etmektedir. Aydoğdu Çelik (2020, s. 157), İtalyan yazar Bigolina'nın Urania başlıklı eserinde erkek kılık kıyafetine bürünen bir kadın karakterin yeni cinsiyet rollerine sahip olduğunu ve kadın olarak kazanamadığı tüm hakları erkek kılığında kazanabildiğini, böylece toplumda kadına yönelik ön yargı ve ötekileştirmenin açığa çıktığını belirtmektedir.

Yazınsal eserlerde ataerkil yapı, toplum ve zaman sınırı tanımayan bir biçimde yer almaya devam etmektedir. Bu durum, eserlerin okunmasıyla ve kültürler arasında dolaşımıyla her defasında toplumsal cinsiyet rollerinin yeniden üretilmesine neden olmaktadır. "Günümüzde yazınsal ya da felsefi bir metnin, cinsiyetlendirilmiş ya da feminist yorumlamalarını hesaba katmayacak potansiyel bir okuma pratiğinin mümkün olmadığı söylenebilir" (Tuna, Kuleli ve Aliyev, 2020, s. iv). Toplumların kültürel belleği olan ve daha çok küçük yaşlardaki çocuklara okunan masallardan, potansiyel okurunun kültürel bagajı güçlü olan şiirlere veya izleyicilerinin özel bir merak ve ilgi duyarak alımlamaya çalışacağı varsayılan Shakespeare tiyatro oyunlarına kadar her yazınsal metnin gerek örtük gerekse açık bir biçimde kadının ötekileştirildiği içerikler sunduğu görülmektedir. Yazınsal metinleri feminist bakış açısıyla çözümleyen yazınsal feminizm, ataerkil toplum yapısını yeniden üreten bu kültürel belleği bilimsel yöntemlerle incelemektedir. "Yazınsal feminizmde, yazarın ataerkil değerleri benimseyerek toplumun kadınlara yönelik basmakalıp inanış ve kendilerine atfedilen rolleri yerine getirecek şekilde kurguladığı kadın karakterler çözümlenir" (Kaplan, 1985, s. 37). Ancak yazınsal feminizm sadece ataerkil değerleri benimseyen yazarların söylemlerini çözümlemekle kalmayıp feminist yazarların ataerkil değerlere karşı çıktığı ve bu değerleri eserlerinde yıktığı söylemleri de çözümlemektedir. Tuna ve Çelik (2020, s. 28) "cinsiyet ayrımcılığının yeniden üretildiği geleneksel çocuk masallarında bu ayrımcllğın nasıl yıkıldığını” farklı kültürlere ait yeni masallar üzerinde çözümlemiştir. Greene ve Kahn'a (1985, s. 1-2) göre yazınsal feminizm, kadınların başardığı her şeyi görmezden gelen, böylece kadını sessizleștiren ataerkil paradigmaları yapısöküme uğratıp kadın bakış açısını yeniden inşa eden bir çalışma alanıdır.

Bu çalışmada, Orhan Pamuk'un Veba Geceleri başlıklı romanı toplumsal cinsiyet inşasına dayalı feminizm kuramı çerçevesinde çözümlenmiştir. Çalışmanın, hiyerarşik kategorilere ait erkek egemen göstergeleri çözümleyerek yazınsal feminizme katkıda bulunması amaçlanmaktadır.

\section{Orhan Pamuk ve Veba Geceleri}

Türk edebiyatının Nobel ödüllü yazarı Orhan Pamuk, içinde bulunduğumuz pandemi dönemine denk gelen Mart 2021'de Veba Geceleri başlıklı romanını piyasaya sürmüştür. Her ne kadar günümüz pandemi koşullarına ve kısıtlamalarına paralellik gösteren çok sayıda göstergeden oluşsa da Pamuk "[b]en bu romanı 40 yıldır düşündüğüm ve beş yıldır yazdığım düşüncesini okurlarıma yansıttım. Koronavirüs salgını başladığında hepimiz sarsıldık. Salgının başlaması bir anlamda bana; kahramanlarıma, kitaplarımda o

\footnotetext{
Adres | Address

RumeliDE Dil ve Edebiyat Araştırmaları Dergisi $\quad$ RumeliDE Journal of Language and Literature Studies Osmanağa Mahallesi, Mürver Çiçeği Sokak, No:14/8 $\quad$ Osmanağa Mahallesi, Mürver Çiçeği Sokak, No:14/8 Kadıköy - İSTANBUL / TÜRKIYE 34714 Kadıköy - ISTANBUL / TURKEY 34714 e-posta: editor@rumelide.com $\quad$ e-mail: editor@rumelide.com tel: +90 505 7958124, +90 2167730616 phone: +90 505 7958124, +90 2167730616
} 
korkuyu daha çok vermeyi öğretti diyebiliriz"3 açıklamasını yaparak bu romanı yazmaya beş yıl önce başladığını ve günümüz pandemi koşullarının henüz dünyada bilinmediği, hatta COVID-19 adlı hastalığın henüz ortaya çıkmadığı yıllarda bu romanı kurguladığını belirtmiştir.

Roman, 1901 yılında Osmanlı'nın kurgusal 29. vilayeti olan Minger Adası'nda geçmektedir. Padişah V. Murat'ın kızı ve Sultan II. Abdülhamit'in yeğeni olarak tanıtılan kurgusal Pakize Sultan karakterinin, tarihte gerçekte yaşamış olan ablası Hatice Sultan'a yazdığı mektuplardan üstkurmaca anlatıcı Mîna Mingerli'nin üzerinden anlatılan 1901 Osmanlısı'ndaki veba salgını kurgusal Minger Adası'na sıçramış ve burada salgınla başa çıkmak için yürürlüğe konulan karantina kuralları ve şartları okura sunulmuştur. Tarihi bir roman özelliğine sahip bu eserin üstkurmaca anlatıcı Mîna Mingerli'ye ait Giriş bölümündeki bir paragraf, romanda kadın-erkek ilişkileri ve ataerkil toplum yapısının işlenmiş olduğunun göstergesi olmasının yanı sıra sunulan göstergeler bu romanın toplumsal cinsiyet inşasına dayalı feminist kuram yoluyla çözümlenebileceğini işaret etmektedir.

Roman sanatı kendi yaşadığımız hikayeleri başkalarının hikayesi gibi, başkalarının yaşadığı hikayeleri de kendimiz yașamışız gibi yazabilme hünerine dayanır. Bu yüzden kendimi bir padişah kızı, bir sultan gibi hissederken bir romancı gibi davrandığıma kolaylıkla inanıyorum. Ama zor olan veba ve karantina mücadelesini yöneten iktidar sahibi erkeklerle, paşalarla ve doktorlarla özdeşleşmekti. Mîna Mingerli, İstanbul, 2017. (Pamuk, 2021, s. 12)

Romanın Giriş bölümündeki bu söylemde geçen "karantina mücadelesini yöneten iktidar sahibi erkekler, paşalar ve doktorlar" göstergeleri toplumda önemli pozisyonlara erkeklerin egemen olduğunu düşündürmektedir. Yapılan feminist çözümleme sonucunda romandaki toplumsal cinsiyet göstergeleri içeren söylemler yedi başlık altında toplanmıştır. Bu sınıflandırma Tablo 1'de verilmiştir.

Tablo 1. Veba Geceleri başlıklı romandaki toplumsal cinsiyet rolleri göstergelerinin sınıflandırılması

1. Kadın ve erkek karakterlerin okura tanitılması

2. Kadının bir işleve indirgenmesi

3. Kadının “ötekileştirilmiş” konumu

4. İktidarın salt erkeklere ait olması

5. Kadına biçilen toplumsal uzam: Ev

6. Medeni durumda salt "kabullenen" olarak kadın

7. Eril dil kullanımı

Bu sınıflandırmalara ait tüm söylemler “Veba Geceleri'nde Toplumsal Cinsiyet Göstergeleri” başlıklı bir sonraki bölümde verilerek tartışılmıştır.

\section{Veba Geceleri'nde toplumsal cinsiyet göstergeleri}

Bu bölüm yedi alt başlıktan oluşmaktadır. Her bir alt başlıkta Tablo 1'de verilen sınıflandırmaya ait söylemler sunularak tartışılmıştır.

\subsection{Kadın ve erkek karakterlerin okura tanıtılması}


Bir romanda bir karakter ilk geçtiği yerde örtük veya açık bir şekilde anlam taşıyıcı özellikleri ile okura tanıtılır. Yazar, karakterleri okurun zihninde canlandırmasını istediği özellikleriyle tanıtır. Tablo 2'de romandaki kadın ve erkek karakterlerin okura ilk tanıtıldığı söylemlerde geçen özellikleri verilmektedir.

Tablo 2. Romandaki kadın ve erkek karakterlerin tanıtılması

\begin{tabular}{|c|c|}
\hline Romandaki kadın karakterler & Romandaki erkek karakterler \\
\hline Abdülhamit'in yeğeni Pakize Sultan & Eczacı Bonkowski Paşa \\
\hline Damat doktorun karısı Pakize Sultan & Doktor İlias \\
\hline [Bayram'ın] karısı & Vali Sami Paşa \\
\hline Hacı Fehmi Efendi'nin kızı & İzmir Valisi Kıbrıslı Kamil Paşa \\
\hline [Bayram'ın] kızı Zeynep & Gardiyan Bayram Edendi \\
\hline Kolağasının annesi & Rus Çarı Nikola \\
\hline Rum ailelerinden Yanboydakislerin gelini & Demirci köse Kudret \\
\hline hastanın [...] yaşlı karısı & Gordon Paşa \\
\hline arabacının karısı & Arabacı Zekeriya \\
\hline dul tarih öğretmeni Marika & Alman Doktor Robert Koch \\
\hline \multirow[t]{12}{*}{ Zengince bir Rum ailenin kızı Despina } & Vasili adlı bir arabacı \\
\hline & Şeyh Hamdullah Efendi \\
\hline & Eczacı Nikiforo Bey \\
\hline & Kayıkçıbaşı palabıyıklı Aleko \\
\hline & Sandalcı Kozma Efendi \\
\hline & Sandalcı İstepan Edendi \\
\hline & Sandalcılar kahyası Seyit \\
\hline & arkeolog Selim Sahir Bey \\
\hline & Hazım Bey \\
\hline & dükkanın sahibi Kiryako Efendi \\
\hline & şerbetçi dükkanının sahibi Kosti Efendi \\
\hline & kitapçı Medit'in sahibi Mösyö Marsel \\
\hline
\end{tabular}

Tablo 2'de görüldügüu üzere romanda adı verilen kadın karakterler erkek karakterlere göre nicelik olarak daha azdır. Ancak, karakterlerin tanıtımında nitelik farkı daha çok göze çarpmaktadır. Tüm kadın karakterler hangi erkek karakterin kızı, karısı, annesi, gelini veya yeğeni olduğu söylenerek tanıtılmıştır. Böylelikle kadın karakterler toplumsal cinsiyet inşasında bağımsız bireyler olarak görülmemekte, erkek egemen bir toplumda hangi erkeğe hangi yönden ait olduğu ile tanınmaktadırlar. Simone de Beauvoir (1949, s. 18), "insanlık erildir, kadın kendi içinde tanımlanmaz, erkeğe göre durumu ile tanımlanır. Özerk bir birey olarak görülmez. Erkeğin ona dair hüküm verdiği ne varsa kadın odur. Erkeğe göre konumu ile tanımlanır ve tanınır" eleștirisinde bu çözümlemedeki kadın karakterlerin sürekli erkeklere göre tanımlanması ve tanıtılmasını göz önüne sermiştir. Metinde sadece Marika adlı karakter ilk tanıtıldı̆̆ı söylemde mesleği ile okura sunulurken kullanılan "dul" nitelemesi zamanında bir erkeğe ait olduğunu çağrıştırmaktadır. Eşi ölmüş olan erkek karakterler için bu niteleme hiç kullanılmazken kadın karakter için

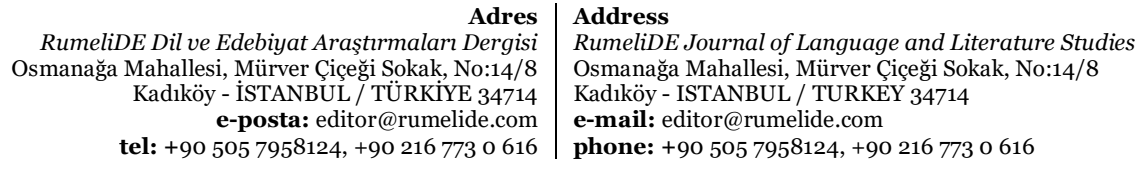


kullanılmış olması feminist çözümleme için önem arz etmektedir. Erkek karakterler ise meslekleri, sahip oldukları mal mülk ve unvanlarıyla okura tanıtılmıştır. Bu durum, erkek karakterlerin meslek ve aile ilişkilerinde bağımsız ve egemen olarak görülmesiyle ilişkilidir. Marika karakteri dışındaki hiçbir kadın karakterin herhangi bir mesleğe sahip olmaması, kadını ekonomik anlamda erkeğe bağımlı hale getirmektedir. Bunun yanı sıra tüm erkek karakterlerin bir mesleğe sahip olarak tanıtılması, eve para getiren kişinin erkek olduğu ataerkil toplum yapısını göz önüne sermektedir. Özellikle Endüstri Devrimi ile başlayan ve erkeklerin evin ihtiyacını karşılamak için dışarıda çalışması, kadının ise evde kalması veya çalışsa da erkeğe göre çok daha düşük maaşla çalışması gibi hiyerarşik inanış romana yansıtılmış ve ataerkil toplum yapısında kadına ve erkeğe biçilen roller yeniden üretilmiştir.

\subsection{Kadının bir işleve indirgenmesi}

Romanda kadın karakterlerin öne çıktığı konular dedikodu yapma veya dış görünüş açısından okura sunularak kadının erkek egemen toplumda işlevinin sadece erkeklerin arzu ettiği eylemleri ve durumları gerçekleștirmek olduğu örtük olarak verilmektedir. Buna dair söylemler Tablo 3'te verilmiștir.

Tablo 3. Romanda kadınların bir işleve indirgendiğine dair söylemler

1. El kremimiz İstanbul'da yalnız Rum eczanelerinde değil, Divanyolu’nda Ali Haydar, Sirkeci'de Beşir Kemal ve Beyazıt'ta İstikamet Eczaneleri'nde de Müslüman hanımlar arasında çok tutulur. (Pamuk, 2021, s. 53)

2. 0 akşam Vali Paşa Marika ile buluştuktan [...] sonra ondan en son dedikodu ve söylentileri dinledi. Bu sefer Marika en inanılmazından başladı: (Pamuk, 2021, s. 144)

3. Marika ilk önemli dedikodu olarak Doktor İlias'ın garnizonda vebaya yakalandığını söyledi. (Pamuk, 2021, s. 188)

4. [...] zaten ablaları gibi güzel ve havalı olmayan Pakize Sultan'ın gerçekçilikle kendini şatafatsız ve sade bir hayata hazırlaması [...] (Pamuk, 2021, s. 198)

Tablo 3'te görüldüğü üzere kadınların işlevi birinci ve dördüncü söylemlerde olduğu gibi güzellik malzemeleri (el kreminin Müslüman hanımlar arasında çok tutulması) ve dış görünüş (ablaları gibi güzel ve havalı olmayan Pakize Sultan) ile sınırlandırılmıştır. Erkeklerin istediği gibi görünmek zorunda bırakılan ve bunun yanı sıra ikinci ve üçüncü söylemlerdeki gibi dedikodu taşıyıcısı olarak erkeklere bilgi verme işlevine indirgenen kadınlar, toplumsal cinsiyet inşasında halen günümüzde dedikodu yapan ve "erkeğine" güzel görünmesi gereken ikincil karakterler olarak görülmektedir. Black ve Sharma’ya (2021, s. 100-101) göre, toplumsal cinsiyet inşasında erkekler eril hegemonyalarını devam ettirebilmek için vücutlarına şekil vermeye çalışırken kadınlardan beklenen toplumsal rol ise doğallıktan sıyrılıp yapay güzellik -makyaj, nemlendirici, saç tasarımları, güzel kokular sürünme- için uğraşmalarıdır. Bu işlevlere indirgenme, kadınların tüm başarılarının göz ardı edilmesine ve toplumda genelde bu özellikleriyle tanınmalarına neden olmuştur. Bu ataerkil değerler romana yansıyarak yeniden üretilmiştir ve yazınsal feminizm açısından özellikle tarihi romanı çözümlemesinde önemli göstergelerdir.

\subsection{Kadının “ötekileştirilmiş” konumu}

Kadının bir işleve indirgenmesi ve "ötekileștirilmiş" konumu arasındaki farkı açıklamak önemlidir. Bir işleve indirgenmiş kadınlara yönelik söylemlerde kadınların erkekler tarafından arzulanan davranışları sergilemesi ve bir obje olarak konumlandırılması söz konusuyken "ötekileștirilmiş" konumdaki kadınlara yönelik söylemlerde sadece erkeklere özgü görülen ve "sağlıklı" bir toplumda kadınların yapmaması gereken, kadınları "yok" sayan, böylece onları "öteki" haline getiren etkinlikler ve durumlar söz konusu olmaktadır. Strelan ve Hargreaves (2005, s. 707) kadının obje olarak konumlandırılması durumunun

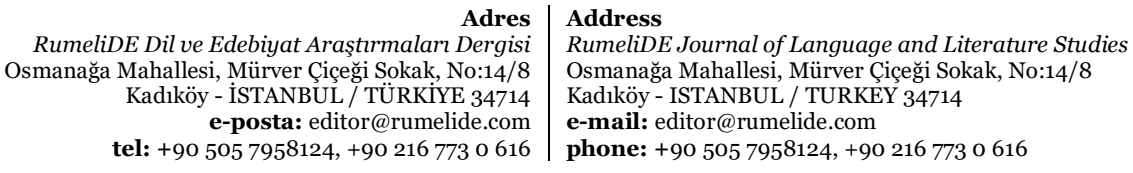


“[kadınların] etraftakilerin bakış açısını benimsemeleri ve fiziksel görünümleriyle anlam kazandıklarına kendilerinin de inanması" ile ortaya çıktığını ifade etmektedir. Bu çalışmada kadının objeleştirilmiş konumu "bir işleve indirgeme" olarak ele alınmıştır. Her ne kadar "post-kolonyal yaklaşımlar 'öteki' kavramını ırk, kadın olma, yerli veya yabancı olma, azınlık ve çok kültürlülük bakımından 'farklı' olma anlamında kullanmıș" (Bălan, 2020, s. 21) olsa da bu çalışmada "öteki” kavramı genel anlamıyla değil kadınları yok sayan ve varlıklarını gölgeleyen söylemler için kullanılmaktadır. Tablo 4'te kadınların "ötekileştirilmiş" konumlarına dair romanda saptanan söylemler verilmiștir.

Tablo 4. Romanda kadınların "ötekileştirilmiş” konumuna dair söylemler

1. Mollalara hiç görünmeyen, yemeklerini odasında yiyen Pakize Sultan da katıldı bu içkisiz yemeğe. Sultan bile olsa o yıllarda bir kadının erkeklerle masaya oturmasının çok nadir bir şey olduğunu hatırlatalım. (Pamuk, 2021, s. 19)

2. "Hayatım boyunca ilk defa bir padişah kızının, bir Sultan’ın İstanbul dışına çıkmasına izin verildiğini görüyorum!" dedi [...] (Pamuk, 2021, s. 21)

3. Hacılar geldikleri ülkelerin görece zenginleriydiler. Bazısı bu hac yolculuğuna çıkabilmek için tarlasını, evini satar, kimileri ylllarca para biriktirir [...] Cava'dan Fas'a dünyanın her yerinden Müslüman erkekler tarihte ilk defa böylesine kalabalıklar halinde bir araya geliyorlar ve birbirlerini tanıyıp temas ediyorlardı. (Pamuk, 2021, s. 71)

4. Kolağası, karısıyla doğrudan konuşmasından kocası rahatsız olabilir diye yalnızca Damat Doktor'a bakarak: [...] dedi. (Pamuk, 2021, s. 73)

5. [...] tarihte İstanbul'dan ayrılan ilk padişah kızı [...] (Pamuk, 2021, s. 77)

6. [...] karılarını, kızlarını muayeneye ikna edecek Müslüman ve tecrübeli doktor ise neredeyse hiç yoktu. (Pamuk, 2021, s. 92)

7. "Meşhur Fransız roman kahramanı, ahlaksız ve şaşkın Bovary de aynı şekilde intihar eder" diye ekledi Bonkowski Paşa'nın kültürlü eski arkadaşı [...] (Pamuk, 2021, s. 202)

8. [...] Osmanlı'da Padişah kızının bile önemli olmaması bazan da hayatlarımızı kurtarmıştır. (Pamuk, 2021, s. 221)

9. [...] kadın ölülerin kireçlenirken yüzlerinin örtülmesi, mahrem yerlerinin ve çıplak vücutlarının görülmemesi, gözükürse de az gözükmesi, [...] gibi pek çok nahoș konu büyümeden, siyasallaşmadan kapandı. (Pamuk, 2021, s. 250)

10. Şeyh Hamdullah döneminin belirleyici özelliği, camilerin ve kiliselerin, tekke ve manastırlarla birlikte, vebaya rağmen ibadete açılmasıydı elbette. Dükkanların, lokantaların, berberlerin hatta bit pazarları ve eskicilerin açılmasına izin verilmesi bile, bu cami-kilise serbestisinin verdiği zarar kadar büyük olmadı. (Pamuk, 2021, s. 411)

11. Başnazır Nimetullah Efendi'den geçmişte karantinaya yardım eden jandarmaların öldürdüğü dedeleri, babaları, ağabeyleri ve kardeşleri için tazminat talep ederek üç yıl önce hukuk hilesiyle kaybettikleri davanın yeniden görülmesini istemişlerdi. (Pamuk, 2021, ss. 415-416)

12. Sokağa çıkma yasağı sabahtan akşam namazına kadar kaldırıldı. Yasak sınırı olarak saatin değil akşam ezan vaktinin konması, bazılarının ileri sürdüğü gibi din etkili siyasi bir karar değildi: Müslüman erkeklerin çoğunun kullanışlı bir cep saati yoktu ve çoğu Damat Doktor'un yeniden koyduğu kilise (çan) ve cami (ezan) yasağından sonra bir kafa karışıklığına kapılmışlardı. (Pamuk, 2021, s. 478)

13. Bir gün: "Sizce, hürriyet ilan edilmiş bir memlekette kadınların mirastan aynı konumdaki erkeklere göre daha az hisse alması makul müdür?” dedi kocasına. (Pamuk, 2021, s. 481)

14. Anneannem Melike'ye Abdülhamit soyundan, tahta çok uzak bir şehzade koca buldular. [...] Anneannem Melike'nin soyunda önemli birisi varsa o da kendi annesi değil, Osmanlı padişahı V. Murat ve onun altı yüz yıllık Osmanlı ailesiydi. (Pamuk, 2021, s. 517)

15. Müslüman kadınların tek başlarına bir arabaya binip herkesin önünde hiç çekinmeden kurabiye yiyebilecekleri bir yer olduğu için de o kadar severim Minger'i. (Pamuk, 2021, s. 522)

Adres

RumeliDE Dil ve Edebiyat Araştırmaları Dergis Osmanağa Mahallesi, Mürver Çiçeği Sokak, No:14/8 Kadıköy - İSTANBUL / TÜRKIYE 34714 e-posta: editor@rumelide.com tel: +90 $5057958124,+902167730616$
Address

RumeliDE Journal of Language and Literature Studies

Osmanağa Mahallesi, Mürver Çiçeği Sokak, No:14/8

Kadıköy - ISTANBUL / TURKEY 34714

e-mail: editor@rumelide.com

phone: +90 5057958124, +90 2167730616 
Projections of feminist reading to literary translation: The Case of Veba Geceleri (Nights of Plague) by Orhan Pamuk / M. Kuleli (pp. 284-306)

Tablo 4'te yer alan söylemler, ataerkil toplum yapısının kadınlara uygun görmediği davranışları içermektedir. Kadınların bu davranışlarda bulunması toplumsal olarak hoş görülmezken normlar dışına çıkıldığı savıyla toplumda "öteki” konumunda görülmeleri söz konusu olmaktadır. Birinci söylemdeki "bir kadının erkeklerle masaya oturmasının çok nadir bir şey ol[ması]”; dördüncü söylemdeki “[bir erkeğin] karısıyla doğrudan konuşmasından kocası[nın] rahatsız olabil[mesi]”; on beşinci söylemde de “[m]üslüman kadınların tek başlarına bir arabaya binip herkesin önünde hiç çekinmeden kurabiye yiyebil[meleri]" gibi sıradan bir olayın dahi kadınlara bahşedilmiş bir özgürlük gibi sunulmuş olduğuna dair göstergeler toplumsal olarak inşa edilen cinsiyet değerlerinde kadınların, erkeklerin görebilecekleri yerlerde bulunmamasını gerektirmektedir. Bir kadından beklenen bu sakınma, şayet kadınlar tarafından uyulmazsa kadınların "iffetten yoksun" olarak görülmesine ve "öteki” pozisyonunda görülmesine neden olmaktadır.

İkinci söylemdeki "ilk defa bir padişah kızının [...] İstanbul dışına çıkması”; beşinci söylemdeki “i̇stanbul'dan ayrılan ilk padişah kızı"; sekizinci söylemdeki "Osmanlı'da bir padişah kızının bile önemli olmaması"; on dördüncü söylemdeki "soyunda önemli birisi varsa o da kendi annesi değil, Osmanlı padişahı V. Murat" göstergeleri, sadece halk içinde değil, yönetici kesimde dahi kadınların "önemsiz" ve "öteki” varlıklar olarak görüldüklerine işaret etmektedir. Tüm hiyerarşik sınıflandırmalar içerisinde en öne çıkan "ötekileştirici" faktörün cinsiyet olduğu, bunun da kadının aleyhine olduğu açıktır.

Üçüncü söylemde geçen "hacılar[ın] [...] müslüman erkekler"den oluşması göstergesi, dini olgularda erkeklerin egemen olduğunu ve kadınların hacı olamayacak "öteki” varlıklar olarak görüldüğünü, ayrıca "hac yolculuğuna çıkabilmek için tarlasını, evini sat[ması]" göstergeleri de aile yaşamında mal sahibinin erkek olarak görüldüğünü, kadının hem dini hem de ekonomik bakımdan erkeklerle bir eşitliğe sahip olmadığını işaret etmektedir. Altıncı söylemdeki "karılarını, kızlarını muayeneye ikna edecek Müslüman ve tecrübeli doktor" arayışı da bir önceki söylemdeki dini ve ekonomik boyutların yanı sıra tıbbi boyutta da erkeklerin var olan her imkandan faydalanabildiğini ancak kadınların sağlık meselelerine dahi erkeklerin karar verdiğinin göstergesidir. Dokuzuncu söylemde yer alan "kadın ölülerin kireçlenirken yüzlerinin örtülmesi, mahrem yerlerinin ve çıplak vücutlarının görülmemesi, gözükürse de az gözükmesi" göstergeleri, sadece hayattayken değil öldüğünde bile kadınların cenaze işlemleri ve süreçlerinin erkekler tarafından kararlaştıııldığını ve erkeklerin uygun gördüğü șekilde defnedilebileceklerini açığa çıkarmaktadır. Bu konunun "siyasallaşmadan kapan"ması göstergesi ise romanın giriş bölümünde ifade edildiği üzere tüm karantina sürecine erkeklerden oluşan bir heyetin karar verdiğine bir atıftır. Bu söylem, ölmüş kadının dahi ölmüș erkeğe göre toplumdaki "ikincil" pozisyonunu göstermektedir. Onuncu söylemde geçen "camilerin ve kiliselerin, tekke ve manastırlarla birlikte, vebaya rağmen ibadete açılması" karantinanın sona erdirilmesi ile açılan ibadethanelerin, öykü zamanında sadece erkeklerin gidebildiği yerler olması hem kadının dini bakımdan hem de yasal bakımdan "ikincil" ve "ötekileştirilmiş" pozisyonunu göstermektedir. Karantinanın sona erdirilmesi kararı sadece erkeklerin "lehine" bir karar olarak alınmış ve toplumda kadınlardan yapmaları beklenmeyen ibadethaneye gitme erkeklere mahsus bir imtiyaz olarak görülebilir. On birinci söylemdeki "jandarmaların öldürdüğü dedeleri, babaları, ağabeyleri ve kardeşleri için tazminat talep" edilmesi olayındaki dede, baba, ağabey göstergeleri sadece erkekler için kullanılabilen akrabalık adları olması nedeniyle yasa önünde hakkı aranabilecek kişilerin sadece erkekler olduğu çıkarımı yapılabilir. Türkçede "kardeş" göstergesi herhangi bir cinsiyet belirtmezken, hem şu ana kadar romanda yapısöküme uğratılan erkek egemen toplum göstergeleri hem de bu söylemin bağlamı "kardeş" göstergesinin de erkek kardeşler için kullanıldığını düşündürmektedir. Toplumsal yasa inşasında kadının olmaması, kadının "öteki” olarak görüldüğünü göz önüne sermektedir. Bu söylemde kadına dair hiçbir gösterge olmaması, yani gösterge yokluğu da kadının "ikincil” pozisyonuna dair önemli bir gösterge olarak düşünülmektedir. On ikinci söylemde geçen "[s]okağa çıkma yasağı[nın] sabahtan akşam namazına kadar kaldırıl[ması]" ve bunun sebebi olarak "[m]üslüman erkeklerin çoğunun kullanışlı bir cep saati

Adres | Address

RumeliDE Dil ve Edebiyat Araştırmaları Dergisi $\quad$ RumeliDE Journal of Language and Literature Studies

Osmanağa Mahallesi, Mürver Çiçeği Sokak, No:14/8 $\quad$ Osmanağa Mahallesi, Mürver Çiçeği Sokak, No:14/8

Kadıköy - İSTANBUL / TÜRKIYE 34714 Kadıköy - ISTANBUL / TURKEY 34714

e-posta: editor@rumelide.com e-mail: editor@rumelide.com

tel: +90 505 7958124, +90 2167730616 phone: +90 505 7958124, +90 2167730616 
[olmaması]"nın gösterilmiş olması, karantina yasaklarına ve bu yasakların gevşetilmesine sadece erkeklerin hesaba katılarak karar verildiğini ve kadının yok sayıldı̆̆ını, dolayısıyla “ikincil” bir pozisyona bile sahip olmadığını düşündürmektedir. Toplumda kabul edilmiş bir inanış olan kadınların ibadethaneye gitmeden kendi evlerinde ibadetlerini gerçekleștirmesi gereği ve ibadethanelerin dahi erkeklere özgü görülmesi, salt olarak toplumsal olarak inşa edilmiş cinsiyet rolleri ile açıklanabilir. On üçüncü söylemdeki "kadınların mirastan aynı konumdaki erkeklere göre daha az hisse alması" geleneği, hem ekonomik hem de yasal olarak kadından beklenen davranışın erkekten daha az mala ve mülke sahip olmasına dayandırılabilir. Toplumsal olarak bu beklenti, ataerkil yapıda erkek kardeşin ailenin devamının sağlayıcısı olarak görülmesi, kadının ise evlendiğinde başka bir eve gitmesi uygulamasından kaynaklanmaktadır. Evlilik durumunda dahi kendi evini terk ederek başka eve taşınmak zorunda olması beklenen taraf kadın olarak görülmekte ve ailenin devamlılı̆̆ında ailenin dışındaki "öteki” konumuna oturtulmaktadır. Bu paragrafta çözümlenen söylemlerin tümü kadının dini, ekonomik, yasal, kültürel ve toplumsal olarak erkekle klyaslanarak "öteki" konumunda ve "ikincil" öneme sahip, bazense hiçbir öneme sahip olmayan kişiler olarak görülmesine işaret etmektedir.

Son olarak Tablo 4'teki yedinci söylemde geçen "Fransız roman kahramanı, ahlaksız ve şaşkın Bovary" göstergesi, Gustave Flaubert tarafından yaratılan Madam Bovary karakterine metinlerarası bir atıf yapmaktadır. Eserdeki Madam Bovary karakteri, eşinden başka erkeklerle ilişki kurması nedeniyle "ahlaksız ve şaşkın" olarak nitelenmiştir. Ancak bu çalışmada çözümlenen romandaki Vali Sami Paşa, Şeyh Hamdullah'ın erkek kardeși gibi karakterler de eşleri dışında başka kadınlarla ilişki içinde olmasına rağmen bu gibi ötekileştirici nitelemelerle karşımıza çıkmamaktadır. Dolayısıyla bu durum, erkeğin eşinden başka kadınlarla birlikte olmasının toplum tarafından doğal karşılandığını, aynı eylemi bir kadın yaptığında ise "öteki” pozisyonuna düştüğünü göz önüne sermektedir. Romanda erkek karakterlerin bu eylemleri övülmemektedir lakin kadın için kullanılan ötekileştirici göstergelerin erkek için kullanılmamış olması, gösterge yokluğunun da bir gösterge olabileceği gerçeğiyle yorumlanabilir.

\section{4. İktidarın salt erkeklere ait olması}

Romanın Giriş bölümündeki “veba ve karantina mücadelesini yöneten iktidar sahibi erkekler” ifadesi roman boyunca sık sık karşımıza çıkan bir olgudur. İktidarın erkeklerin tekelinde olduğuna dair romanda saptanan söylemler Tablo 5’te verilmiştir.

Tablo 5. Romanda iktidarın salt erkeklere ait olmasına dair söylemler

1. Fesli, kavuklu ve şapkalı on yedi heyet üyesinin, din adamlarının, askerlerin, çevirmenlerin ve bürokratların arasına Abdülhamit yeni evlendirdiği yeğeni Pakize Sultan ile kocası Damat Doktor Nuri Bey'i son anda katmıştı. (Pamuk, 2021, s. 15)

2. Pakize Sultan'ın büyük büyükdedelerinin altı yüzyıl önce kurduğu Osmanlı İmparatorluğu’nun son haliydi bu. (Pamuk, 2021, s. 31)

3. Mabeyn ve Babıali bu gelişmeleri Vali'ye bildiriyor, Vali, Damat Doktor'la konuyu tartışıyor, sonra Damat Doktor karısıyla paylaşıyor, Pakize Sultan da onlardan işittiklerini ablasına yazıyordu. (Pamuk, 2021, s. 211)

4. “Rum cemaati reisi Konstantinos Efendi hazretleriyle daha dün görüştüm ...” dedi Konsolos Corc. (Pamuk, 2021, s. 273)

5. [...] eski şeyhlerden birinin [...] gür ve beyaz sakalı [...] (Pamuk, 2021, s. 283)

6. Telaşlı, korkulu müminler bu ayrıntıları anlayabilecek kadar sakin değillerdi [...] Şeyh Hamdullah içten sözlerini dikkatle dinleyen sakallı, yorgun erkeklerin çoğunu tanıyordu. (Pamuk, 2021, s. 305)

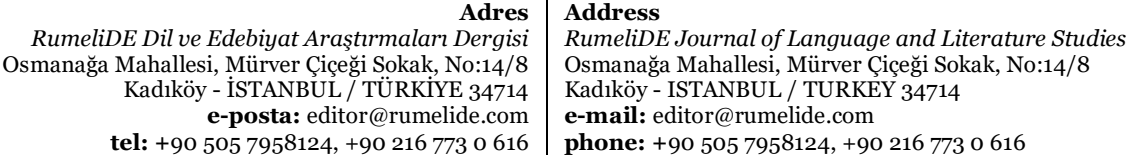

RumeliDE Dil ve Edebiyat Araştırmaları Dergisi el: +90 $5057958124,+902167730616$ 
Projections of feminist reading to literary translation: The Case of Veba Geceleri (Nights of Plague) by Orhan Pamuk / M. Kuleli (pp. 284-306)

7. Biz tarih kitabımız için balkondakilerin bir dökümünü yapalım: Şeyh Hamdullah, Ortodoks cemaati başı Bașpapaz Konstantinos Laneras, eski vali Sami Pașa, Damat Doktor Nuri, bütün konsoloslar, Murakabe Müdürü Mazhar Efendi ve bugün kimliklerini çıkaramadığımız iki kişiyle beş muhafız. (Pamuk, 2021, s. 325)

8. Adada her zaman yașanan (ve hep savunduğumuz) laik kardeșliğin bir simgesi olan anı gösterir fotoğraflar, birkaç yıl sonra ne yazık ki, "Minger Devleti'nin kurucuları devletin uzun ömürlü olması ve herkese mutluluk ve huzur getirmesi için dua ederlerken çekilmiştir" diye tanıtılmıştır. (Pamuk, 2021, s. 331)

9. Kalabalık bir süre sonra Sami Paşa'nın sözlerinden kendilerini yeni müstakil Minger Devleti'nin Anayasa'sını hazırlamak ya da ona onay vermek gibi zor bir görevin beklediğini de anladılar. Masanın kenarında söylenen anayasa maddelerini yazacak iki katip oturuyordu.[...] “Devlette kararlar Minger Milleti adına alınır.” [...] Herkes bu mantıkla hareket ederse Vilayet binasında, yeni Başnezaret'te kimsenin oda değiștirmesine bile gerek kalmayacaktı. (Pamuk, 2021, s. 339)

10. "Mühim bir misafiriniz var" dedi Corc Bey dikkatle. "Pakize Sultan, Osmanlı ailesinden çok özel bir şahsiyettir. Padişah kızının diplomatik bir kıymeti vardır." "Osmanlı ananesinde ailenin kadın kolundan hiçbir kimsenin tahtla ilişkisi yoktur ve millet bunu kabul etmez.” (Pamuk, 2021, s. 375)

11. Ama Başnazır önce "Minger'in önde gelenleri” dediklerinin kimler olduğunu açıkladı: Rum cemaati başı başpapaz Konstantinos Efendi; kendisi; cezasını evinde çekmekte olan eski Murakabe Müdürü; bazı yaşlı zengin Rum ve Müslümanlar; biri Rum iki yaşlı gazeteci; Nikos Bey; bazı doktorlar, başta İngiliz konsolosu olmak üzere üç konsolostan oluşuyordu bu heyet. (Pamuk, 2021, s. 446)

12. Salgınhane odasındaki sabah toplantılarına Kraliçe Pakize de katılıyordu. [...] toplantılarda arkada oturuyordu. (Pamuk, 2021, s. 464)

13. Altı ülkenin birer temsilcisinden oluşan bir heyet Arnavutluk'u yönetecek, ülkenin başında bir de Düvel-i Muazzama'nın seçtiği Prens olacaktı. (Pamuk, 2021, s. 513)

14. Doktor Nuri on iki yıl önce Minger'de İngiliz konsolosu Corc'a söylediği şeyi aynı ciddiyetle tekrarladı ve bir Müslüman ülkesinde padişah kızının, yani ailenin kadın kolunun hiçbir siyasi gücü olmayacağını söyledi. (Pamuk, 2021, s. 514)

Birinci söylemde Sultan Abdülhamit'in Çin'e gönderdiği gemide bulunan heyet üyelerinin, yani Çin'deki Müslüman halk üzerinde söz sahibi olması beklenen iktidar sahiplerinin Pakize Sultan dışında "[f]esli, kavuklu ve şapkalı" göstergeleriyle erkek olduğu anlaşılan "on yedi heyet üyesin[den], din adamların[dan]" oluşmuş olması, toplumda karar verici ve yönlendirici güç olarak erkeklerin egemen konumda olduğunu göstermektedir. Diğer heyet üyeleri olan "askerler, çevirmenler ve bürokratlar" herhangi bir cinsiyete atıf yapıyor olmasa da şu ana kadar çözümlenen tüm söylemler ve bu söylemin bağlamı özelinde bu heyet üyelerinin de erkek olduğunu düşündürmektedir. İkinci söylemde yer alan "büyükdedelerinin altı yüzyıl önce kurduğu Osmanlı İmparatorluğu" ifadesinde devletin kurucusu olarak salt erkekler gösterilmektedir. Üçüncü söylemde önceki padişahın kızı mevcut padişahın yeğeni olarak kurgulanan Pakize Sultan yer almaktayken Osmanlı yönetiminden gelen tüm bilgiler, Minger Adası'nın en yüksek yerel amiri olan Vali Sami Paşa'ya ve ondan da Pakize Sultan'ın eși Damat Doktor'a bildirilmektedir. Bu göstergeler, Osmanlı merkezi yönetimi ile Minger Vilayeti arasındaki tüm görüşmelerin sadece erkekler tarafından yapıldı̆̆ını açıkça göstermektedir. Dördüncü söylemde geçen "Rum cemaati reisi Konstantinos Efendi” karakterindeki "Efendi" göstergesi ve "Konsolos Corc" karakterindeki "Corc" adının toplumsal inşaya dayalı sadece erkeklere veriliyor olması dini liderin ve yabancıların en yüksek temsilcisinin; beşinci söylemdeki "eski şeyhlerden birinin" sakalından bahsedilerek dini bir diğer liderin; altıncı söylemdeki "Şeyh Hamdullah" karakterinin adının yine toplumsal inşaya dayalı olarak sadece erkeklere özgü bir ad olması diğer bir dini liderin; yedinci söylemdeki “Ortodoks cemaati başı Başpapaz Konstantinos Laneras” karakterindeki "Konstantinos" adının erkeklere verilmesi nedeniyle ve aynı söylemde geçen "Murakabe Müdürü Mazhar Efendi" karakterindeki "Efendi" göstergesinin erkekler için kullanılıyor olması nedeniyle hem bir dini

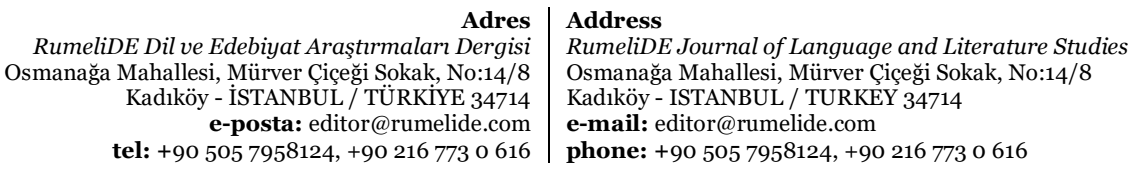


liderin hem de müdürün, yani bir iktidar sahibinin erkek olduğunu açı bir biçimde göz önüne sermektedir. Dokuzuncu söylemde hazırlanmakta olan yeni devlet anayasası, yani tüm toplumu yönetmede kullanılacak olan kurallar verildikten sonra "[v]ilayet binasında, yeni Başnezaret'te kimsenin oda değiştirmesine bile gerek kalmayacak” cümlesi, Minger Adası Osmanlı'ya bağlıyken tamamen erkeklerden oluşan yönetim kademesindeki herkesin iktidar koltuğunda kalacağının işaretidir ve tüm toplumu yönetecek olan kurallar tamamen erkelerden oluşan heyet tarafından hazırlanarak yine tamamen erkeklerden oluşan yönetim kadrosu tarafından uygulatılacaktır. Onuncu söylemdeki "Osmanlı ananesinde ailenin kadın kolundan hiçbir kimsenin tahtla ilişkisi yoktur" cümlesi devletin tamamen erkekler tarafından yönetildiğini; "millet bunu kabul etmez" cümlesi ile ataerkil yapının toplumda benimsendiğini işaret ederken son cümledeki "millet" göstergesinin de erkekler için kullanılmış olabileceği yorumunu doğurmaktadır zira "yok" konumundaki kadının bunu kabul edip etmeme gibi bir tercihte dahi bulunamayacağı açıktır. On birinci söylemde sayılan "Minger'in önde gelenleri", "Efendi", yedinci söylemde çözümlenen "Müdür" ve "Bey" göstergelerine bakıldığında yine erkeklerdir. Bu söylemdeki "zengin Rum ve Müslümanlar" göstergesinin de erkeklere atfettiği açıktır zira toplumda mal ve mülk sahibi sadece erkekler olabilmektedir. Kadının yeri "ev" olarak gösterilip tüm meslekler erkeklere ait olması nedeniyle evdeki iktidar sahibi de erkek olarak karşımıza çıkmaktadır. "İki yaşlı gazeteci” ve "doktorlar” için herhangi bir cinsiyet göstergesi bulunmasa da romanda geçen her türlü mesleği sadece erkekler yaptığı için ve romanın Giriş bölümünde doktorların erkek olduğu söylendiği için bu karakterlerin de erkek olduğu çıkarımı yapılabilir. Bu söylemdeki üç konsolosun ise romanın diğer bölümlerinde erkek karakterler olduğu görülmektedir. Bu durumda, “Minger'in önde gelenleri”, yani iktidar sahibi sadece erkeklerdir. On ikinci söylemde Pakize Sultan'ın heyet toplantılarına iştirak ettiği ancak en araka oturduğu söylenerek herhangi bir etkisinin olmadığı ve yönetim kademesinde de cinsiyete dayalı bir hiyerarşi olduğu açık hale getirilmektedir. On üçüncü söylemde Arnavutluk ülkesini yönetecek olan bir "Prens" olarak tanıtılması yine iktidarın bir erkeğin elinde olacağını, hatta onu seçecek olan altı ülkenin gönderdiği heyet üyelerinin de erkek olduğu yorumunu doğurmaktadır. On dördüncü söylemdeki "ailenin kadın kolunun hiçbir siyasi gücü olmayacă̆ı" ifadesi de kadını yok sayan ve yönetim gücünün tamamen erkeklerde olduğunu gösteren bir göstergeler bütünüdür.

Son olarak, sekizinci söylemde geçen "laik kardeşlik" göstergesi içinde kadın-erkek eşitliğini barındırırken, söylemde bahsedilen "fotoğraflar", "Minger Devleti'nin kurucuları" salt erkeklerden oluştuğu için tamamen erkekleri içermektedir. Bu durum, "laik kardeşlik" göstergesinin sadece erkeklerin kendi aralarındaki eşitliği belirttiğini düşündürmektedir. Burada tartışılan on dört söylemin tümünde siyasi, dini, toplumsal, mesleki ve temsilsel tüm iktidar sahiplerinin erkek olduğu görülmektedir.

\subsection{Kadına biçilen toplumsal uzam: Ev}

Endüstrileşme ile birlikte topluma arz edilen metalara sahip olabilmek için dışarıda çalışmaya başlayan erkeği geri kalan ev işlerini yerine getirmekle yükümlü bir kadın takip etmiştir. Salt erkeğin getirdiği para ile geçinemeyen ailelerde daha düşük ücrete dışarıda çalışmak zorunda kalan kadınlar ise erkeğin ev işlerini üstünden atmasıyla ele geçirdiği avantaja sahip olamayıp dışarıda kapitalizm tarafından evde ise erkek tarafından sömürülmeye başlamıştır. Erkeğin her durumda egemen olduğu bu kapitalist "düzen" ile birlikte ataerkil toplum yapısı daha da güçlenmiş ve çalışmayan kadının (ki çoğunluğu çalışmazdı) salt toplumsal uzamını ev olarak, dışarıda çalışan kadının toplumsal uzamını ise kapitalist fabrika sahiplerinin sömürmediği zamanlarda yine ev olarak belirleyip ev işleri ve çocuk bakımını kadına uygun görmüștür. Romanda kadının toplumsal uzamına dair açık ve örtük göstergeler içeren söylemler Tablo 6'da verilmiştir.

Tablo 6. Romanda kadının toplumsal uzamına dair söylemler

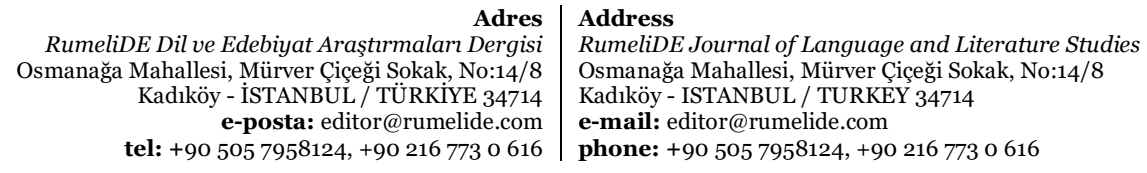


Projections of feminist reading to literary translation: The Case of Veba Geceleri (Nights of Plague) by Orhan Pamuk / M. Kuleli (pp. 284-306)

1. Nöbetler, küçük isyanlar, kavgalar yüzünden at arabasıyla on dakika uzaklıktaki evine bazı geceler dönmediği için karısı ve kızı Zeynep merak etmediler onu. (Pamuk, 2021, s. 25)

2. [...] son kere evinden karısıyla, kızıyla vedalaşmadan bahçeye abdesthaneye gider gibi çıkmıştı. Karısı, kızı iyileşeceğine inanmadıkları için arkasından ağladılar. (Pamuk, 2021, s. 28)

3. Geniş Hamidiye Caddesi'nin çınar ve akasya ağaçlarının altından yürüyen şapkalı, fesli beylerle, çarıklı köylülerle karşılaştılar. (Pamuk, 2021, s. 44)

4. [...] boş bir arsa içinde ağaçlar arasında çamaşır asarken aralarında bağrışarak gülüşen kadınlar [...] (Pamuk, 2021, s. 61)

5. [...] İstanbul Caddesi üzerinde tek tük insanlar yürüyordu. Kolağası onların şapkalarını, feslerini uzaktan da olsa görmekten mutluluk duydu. (Pamuk, 2021, s. 75)

6. Rıhtım Caddesi'nden yukarı doğru ilerlerken, sokaklardaki şapkalı, fesli kişilerin merakla kendilerine baktıklarını gördü konuklar. (Pamuk, 2021, s. 78)

7. Osmanlı taşrasının en gelişmiş şehirlerinde bile sokaklarda görülen kravatlı-şapkalı herkesin Hıristiyan olduğunu göz kendiliğinden bilirdi. (Pamuk, 2021, s. 79)

8. Doktor Jean-Pierre de veba yayıldıkça, istemeye istemeye de olsa askerlerin yardımıyla konutların kapılarını kırıp açmaya, analarla çocukları zorla ayırmaya [...] başlamış (Pamuk, 2021, s. 91)

9. Vali Paşa sokaklarda çocuklarıyla eve yetişen kadınlar [...] gördü. (Pamuk, 2021, s. 122)

10. “Döktükleriniz hediyem olsun! Lakin şimdi biz evde ne yiyeceğiz, neyle geçineceğiz!” demişti şerbetçi Kosti. (Pamuk, 2021, s. 138)

11. Damat Doktor, evlenmelerinden beri ilk defa karısının bir sözüne alınıp kalbi kırılınca kendini odadan dışarı attı. Düşüncelere dalınca şehirde gelişigüzel yürümekten hoşlanıyor. (Pamuk, 2021, s. 155)

12. [...] beyefendilerin gülüșerek dedikodu yaptığı sokak kahvelerinde, Rum madamların ve uşakların bahriyeli elbisesi giyen çocukları gezdirdiği kaldırımlarda [...] (Pamuk, 2021, s. 167)

13. Bir arka bahçede başörtülü bir kadın dünyanın en sıradan gününü yaşar gibi, bir ipe çamaşırlar asıyor [...] (Pamuk, 2021, s. 213)

14. Kendilerini evlerine kapatan erkeklerin çoğu bir süre sonra sıkılıyor, sabırsızlığa, meraka kapılıyor, cumbadaki kafesi aralayıp dışarıyı dikizliyor, sağa sola laf atıyordu. (Pamuk, 2021, s. 226)

15. Çocukluğunda Postane [...] hamarat bir ev kadınının mutfağı gibi düzenliydi. (Pamuk, 2021, s. 264)

16. Bazı memurların, mesela Evkaf Müdürü Nizami Bey (yeni evlenmiști, karısı İstanbul'daydı) ya da Hazine Müdür Muavini Abdullah Bey'in (adaya bir tülü ısınamamış, sevmemişti burayı) İstanbul'a hemen dönmek istemelerini çok iyi anlıyordu. Kafası karışık olacağına inandığı Murakabe Müdürü (karısı zengin ve adalı bir ailedendi) ve Şifre Katibi Mehmet Fazıl Bey gibi memurları anayasayı hazırlayacak heyete, burada kalmaları örnek olur diye koymuștu. [...] Sami Paşa İstanbul'a sadık, kafası karışık bu memurları tek tek tanıyor, neşesiz, keyifsiz hallerinin arkasındaki, bir gün Abdülhamit'in verebileceği cezaların dehșetini ve karısını, çocuğunu bir daha görememe, eve hiç dönememe korkusunu yüzlerinde görüyordu.[...] Teselli Kaymakamı Rahmetullah Efendi [...]. (Pamuk, 2021, ss. 344-345)

17. Çocukluğumda karıştırdığım eski Minger dergilerinde ailelerini, mahallelerini besleyen, yaşatan bu kahraman çocukları ağ ve fileyle yeşil renkli bir alabalık avlarken gösterir bir resimden çok etkilendiğimi burada söylemeliyim. Yüz on altı yıl önce yaşasaydım ve kız değil erkek olsaydım bu neşeli çocukların arasında ben de olabilirdim. (Pamuk, 2021, s. 354)

18. Bir yerde, bir yokușta bir cenazeden diğerine, bir evden ötekine koșan iyi niyetli Müslüman erkekler kalabalığı hep vardı. (Pamuk, 2021, s. 378)

19. Pakize Sultan'ın tereddüt ettiğini gören Başnazır Nimetullah kraliçe olmanın sembolik yanını vurgulamak için: "Aslında yine isterseniz misafir odanızdan hiç çıkmayacaksınız!" demişti. (Pamuk, 2021, s. 448)

20. Çeşitli yaşlarda köylü kıyafetli on bir erkek satıcı vardı burada. (Pamuk, 2021, s. 450)

21. Bahçelerde birbirlerine sarılarak ağlayan kadınlar, koşturan çocuklar ve köpekler, bir kenara yatırılmış ölüler, çamaşır asan kadınlar, yataklar, masalar, büyük su küpleri gördüler. (Pamuk, 2021, s. 453)

22. [...] müebbete mahkum Mazhar Efendi zindandan salıverildi ve cezasını adalı karısı ve çocuklarıyla evinde çekmeye başladı. (Pamuk, 2021, s. 457)

Adres

RumeliDE Dil ve Edebiyat Araşturmaları Dergis Osmanağa Mahallesi, Mürver Çiçeği Sokak, No:14/8 Kadıköy - ISTANBUL / TÜRKIYE 34714 e-posta: editor@rumelide.com tel: +90 $5057958124,+902167730616$
Address

RumeliDE Journal of Language and Literature Studies

Osmanağa Mahallesi, Mürver Çiçeği Sokak, No:14/8

Kadıköy - ISTANBUL / TURKEY 34714

e-mail: editor@rumelide.com

phone: +90 5057958124 , +90 2167730616 
23. [...] insanlar mahalle sorumlusu ve Karantina Neferleri'nin yönlendirmesiyle sıraya girip ekmeklerini alıyorlardı. Kişi sayısına göre, her evin önde gelen erkeğine veriliyordu ekmekler. (Pamuk, 2021, s. 463)

24. Yaklaşan kışa hazırlık olarak halıları, kilimleri, hasırları pencerelerden sarkitıp ya da bahçeye çıkarıp çamaşır sopasıyla tozu çısıın diye döven kadınların pat pat seslerine de kulak verdi Pakize Sultan. (Pamuk, 2021, s. 479)

25. Sonraki iki yılda da Pakize Sultan'ın ablasına daha az mektup yazmasının bir nedeni duyduğu kederse [...] diğeri kızı Melike'nin 1906'daki doğumunun onu çok meşgul etmesidir. (Pamuk, 2021, s. 503)

26. 1909-1913 yılları arasındaki beş yılda Pakize Sultan ablasına toplam on bir kısa mektupta hep aynı şeyleri, çocuklarıyla Hong Kong'da iyi olduklarını, kocasının çok çalıștığını, kendisinin de ev işleriyle ve roman okumakla meşgul olduğunu yazdı. (Pamuk, 2021, s. 510)

27. Kızı Melike o sırada yedi yaşındaydı ve annesinin kendisine Arnavut prensesi şakaları yaparken bir yandan da ev işlerine baktığını, hizmetçisinin tembelliğinden şikayet ettiğini hatırlayacaktır. (Pamuk, 2021, s. 515)

Tablo 6'daki birinci ve ikinci söylemlerde Minger hapishanesinde görevli olan karakterin "evine bazı geceler dönmediği" ve "evinden [...] abdesthaneye gider gibi çık[tı̆̆ı]" durumlarda evde kalanlar her iki söylemde de "karısı ve kızı" olmaktadır. Üçüncü söylemde caddede "yürüyen şapkalı, fesli beyler"; beşinci söylemde "İstanbul Caddesi üzerinde yürüyen" ve toplumsal inşa sonucunda sadece erkeklere ait giysiler olan "şapka" ve "fes" takan insanlar; aynı giysilerle altıncı söylemde "Rıhtım Caddesi'nde"ki insanlar; yedinci söylemde "Osmanlı taşrasının en gelişmiş șehirlerinde bile sokaklarda görülen" ve toplumsal inşa sonucu salt erkeklere ait olarak görülen "kravatlı-şapkalı" herkes; on birince söylemde eşiyle tartışınca "kendini odadan dışarı at[an]" Damat Doktor; on ikinci söylemde "gülüşerek dedikodu yap[ılan] sokak kahvelerinde[ki] beyefendiler; on altıncı söylemde "Abdülhamit'in verebileceği cezaların dehşeti[yle] karısını, çocuğunu bir daha görememe" ve "eve hiç dönememe" korkusu yaşayan memurlar (karısını görememe korkusu yaşadığına göre hepsi erkek); on yedinci söylemde alabalık avlayarak "ailelerini, mahallelerini besleyen, yaşatan" erkek çocukları ve bundan mahrum kalan kız çocuğu; on sekizinci söylemde "bir yokuşta bir cenazeden diğerine, bir evden ötekine koşan iyi niyetli Müslüman erkekler kalabalığı”; yirminci söylemde pazara ürün satıp para kazanmak için çıkan "on bir erkek satıcı"; yirmi ikinci söylemde hapisten salınarak "cezasını adalı karısı ve çocuklarıyla evinde çekmeye başla[yan]" Mazhar Efendi; son olarak yirmi üçüncü söylemde tam karantina günlerinde ekmek dağıtılırken sokağa ailesi için ekmek almaya çıkan "her evin önde gelen erkeği" romanda evden dışarıda tasvir edilirken bu sokaklarda, caddelerde, pazarlarda veya şehrin herhangi bir yerinde nadir de olsa dışarı çıkan Pakize Sultan dışında hiçbir kadına rastlanmamıştır. Tablo 6'da evin dışındaki hayatın tasvir edildiği tüm söylemlerde sadece erkekler yer alırken kadına dair herhangi bir gösterge olmaması, bu çözümlemede benimsenen gösterge yokluğunun önemli bir gösterge olabileceği düşüncesiyle desteklenerek kadına biçilen toplumsal uzamın dışarısı olmadığı, sadece ev olduğu sonucuna varılabilir. Ayrıca, dördüncü söylemde "çamaşır asarken aralarında bağrışarak gülüşen kadınlar"; sekizinci söylemde "çocuklarından zorla ayrı [bırakılan]" kadınlar; dokuzuncu söylemde "çocuklarıyla eve yetișen kadınlar"; on üçüncü söylemde bir arka bahçede "bir ipe çamaşırlar as[an]" kadın; on beşinci söylemde Minger Postanesi'nin "hamarat bir ev kadınının mutfağı"na benzetilmesi; on dokuzuncu söylemde "yine [isterse] misafir odanızdan hiç çıkma[ma]" seçeneği sunulan Pakize Sultan; yirmi birinci söylemde "[b]ahçelerde birbirlerine sarılarak ağlayan kadınlar" ve "çamaşır asan kadınlar"; yirmi dördüncü söylemde "kışa hazırlık olarak halıları, kilimleri, hasırları pencerelerden sarkıtıp ya da bahçeye çıkarıp çamaşır sopasıyla tozu çıksın diye döven" kadınlar; yirmi beşinci söylemde "kızı Melike'nin 1906'daki doğumunun onu çok meşgul" ettiği söylenen Pakize Sultan; yirmi altıncı söylemde kocası dışarıda çok çalışırken "kendisinin de ev işleriyle ve roman okumakla meşgul olduğunu" belirten Pakize Sultan; son olarak yirmi yedinci söylemde kızına "Arnavut prensesi şakaları yaparken bir yandan da ev işlerine bak[an] Pakize Sultan, romanda kadının çocuk bakma, yemek yapma, çamaşır yıkama, ipe çamaşır serme ve diğer ev işlerini yapmakla yükümlü olduğunu ve toplumsal beklentinin kadının bu işleri yaparak evinden dışarı çıkmaması olduğunu açıkça göstermektedir. Erkeği hep dışarıda, kadını ise hep evde tasvir eden bu söylemlerin yanı

Adres $\mid$ Address

RumeliDE Dil ve Edebiyat Araştırmaları Dergisi Osmanağa Mahallesi, Mürver Çiçeği Sokak, No:14/8 Kadıköy - İSTANBUL / TÜRKIYE 34714 e-posta: editor@rumelide.com tel: +90 $5057958124,+902167730616$

RumeliDE Journal of Language and Literature Studies

Osmanağa Mahallesi, Mürver Çiçeği Sokak, No:14/8

Kadıköy - ISTANBUL / TURKEY 34714

e-mail: editor@rumelide.com

phone: +90 5057958124 , +90 2167730616 
sıra onuncu söylemde diğer bir erkek karakter olan dükkan sahibi şerbetçi Kosti'nin dükkanındaki malları dökülünce ürettiği "[l]akin şimdi biz evde ne yiyeceğiz, neyle geçineceğiz!" söylemi evden dışarıda para kazanan tek bireyin kendisi olduğunu, karısının ve çocuklarının evde kalarak onun getireceği para ile hayatlarını devam ettireceğini ima etmektedir. Son olarak, on dördüncü söylemdeki “[k]endilerini evlerine kapatan erkeklerin çoğu bir süre sonra sıkılıyor" cümlesi, erkeklerin toplumsal olarak beklenen uzamının dışarısı olduğunu, evde kalmaları durumunda sıkılmaya başladıklarını zira ataerkil toplumda erkeğin dışarıda olması gerektiği inancının kendilerine toplumsallaşma sürecinde öğretildiği çıkarımını doğurmaktadır. Sonuç olarak, Tablo 6'da dışarıların sadece erkeklere ait olduğu, kadınların ise ev işleri için sadece eve ait olduğu söylemleri toplumsal cinsiyet inşası temelli rollerde kadına biçilen "toplumsal" uzamın ev olduğunu göstermektedir.

\subsection{Medeni durumda salt "kabullenen" olarak kadın}

Romanda kadınların nişanlılık, evlilik ve boşanma konularında erkek egemen bit toplumda söz sahibi olmadıkları bulunmuştur. Medeni durumda kadının, erkekler tarafından verilen kararları salt "kabullenen" olarak görüldüğüne dair söylemler Tablo 7'de verilmektedir.

Tablo 7. Romanda kadının medeni durumda salt "kabullenen" olduğuna dair söylemler

1. “[...] Zalim Pavlo'nun [...] kız kaçırmayı, kafası atarsa göz çıkarıp kulak kesmeyi sevdiğini herkes bilir.” (Pamuk, 2021, s. 54)

2. Dört kadınla evlenen Hacı ağalardan, genç kızlarla evlenen yaşlı zenginlerden de nefret ederdi. (Pamuk, 2021, s. 86)

3. Subayların, memurların şehirden ayrılırken "boş ol" deyip unutacaklarını bildikleri evliliklerdendi bu. [...] Bu yüzden Kolağası İstanbul'a tayini çıkınca çok suçluluk duymadan bu Arap güzelini boşamış [...] (Pamuk, 2021, ss. 8687)

4. “İki Müslüman doktor vardı. Biri Hamidiye Hastanesi'nin hiç bitmeyeceğini düşünüp iki yıl önce İstanbul'a geri döndü. Ona adadan bir kız bulup everselerdi, kalırdı [...]” (Pamuk, 2021, s. 91)

5. Marika Müslüman olsaydı, kimi mutasarrıfların yaptığı gibi, İstanbul'daki ilk hanıma haber bile vermeden burada onu ikinci karısı olarak alabilirdi. (Pamuk, 2021, s. 126)

6. "Senin de pencereden gördügün [...]?”

"Paşa hazretleri, [...] sizin uyarınız üzerine[...]"

"Desene bizim tulumbacılar tepegözlüyü kaçırdı!”

"Kederleneceksiniz ama [...]"

"Sen de beni üzmek için [...]" (Pamuk, 2021, s. 144)

7. Zeynep'in gardiyan babası Ramiz ile mal mülk pazarlığını yapmış, paranın bir kısmını alıp hemen iki oğluna vermiş [...] (Pamuk, 2021, s. 148)

8. Kolağası'nın annesinin oğluna anlattığına göre Zeynep, son anda Ramiz'in kuzeyde, Nebiler köyünde bir ikinci karısı (hatta bir üçüncü olduğu da söyleniyordu) olduğunu öğrendiği için vazgeçmiştir o evlilikten. [...] Aslında Zeynep baştan bu ilk karıyı biliyordu ama babasından ve ağabeylerinden korktuğu için evliliğe karşı çıkamıyordu. (Pamuk, 2021, s. 148)

9. Zeynep'in annesi Emine Hanım kızının ancak adadan kaçarak ailesinin ve kendisinin şerefini kurtarabileceğine inaniyordu. (Pamuk, 2021, s. 149)

10. [...] padişah kızlarıyla, sultanlarla evlenen damatların onların üzerine ikinci bir kadın alamama kuralı [...] (Pamuk, 2021, s. 212)

11. Kolağası haberin annesine ne kadar çabuk gittiğine şaştı, bir an hoşuna gitti bu ve "Bana onu al!" demek geldi içinden [...] (Pamuk, 2021, s. 213)

12. Anneler Kolağası'nın vereceği başlık parası, hediye, altın gibi konularda anlaşmış oldukları için bu konuyu hiç açmadılar. (Pamuk, 2021, s. 215)

\begin{tabular}{r|l} 
Adres & $\begin{array}{l}\text { Address } \\
\text { RumeliDE Dil ve Edebiyat Araşttrmaları Dergisi }\end{array}$ \\
RumeliDE Journal of Language and Literature Studies \\
Osmanağa Mahallesi, Mürver Çiçeği Sokak, No:14/8 & Osmanağa Mahallesi, Mürver Çiçeği Sokak, No:14/8 \\
Kadıöy - ISTANBUL / TÜRKIYE 34714 & Kadıköy - ISTANBUL / TURKEY 34714 \\
e-posta: editor@rumelide.com & e-mail: editor@rumelide.com \\
phone: +90 505 7958124, +90 216 773 0616
\end{tabular}


13. [...] birlikte çok mutlu bir hayat yaşadığı iki karısı birden ölünce kendini Kur'an-ı Kerim okumaya vermiş [...] (Pamuk, 2021, s. 218)

14. İlk karısı Ayşe'nin böyle bir huyu olmadığı için Komutan karısı sözünü dinlemeyince ne yapacağını hiç bilemiyor, odayı terk ediyor ve öfkesinin geçmesini bekliyordu. (Pamuk, 2021, s. 380)

15. Kağıt üzerinde kalsa da Şeyh hazretleri ile nikah kıyılabilmesi için Sultan'ın Doktor Nuri'den boşanması gerekiyordu. Bu iki şekilde olabilirdi: “Boş ol!” diyerek Damat Doktor bunu ken di yapabilir ya da kocası dört yıldan fazlaya mahkum olduğu için Pakize Sultan Minger mahkemesine boşanmak için başvurabilirdi. (Pamuk, 2021, s. 439)

Tablo 7'de birinci söylemdeki erkek karakter Pavlo'nun “kız kaçırmayı” sevdiği belirtilirken bu söylemdeki "kız kaçırma" göstergesi eril bir ifadedir. Bir kadının kendi rızası dışında bir erkek tarafından evinden alınıp uzaklaştırılması, hem kadının söz hakkı olmaması hem de evini terk etmek zorunda kalanın kadın olması bakımından ataerkil toplumlarda uygulanan ve erkekleri medeni durumda salt egemen kılan bir eylemdir. İkinci söylemde bir erkeğin "dört kadınla evlenebilmesi"; beşinci söylemde Vali Sami Paşa'nın romanda meslek sahibi tek kadın olan Marika’yı dahi “İstanbul'daki ilk hanıma haber bile vermeden burada onu ikinci karısı olarak" alabilmesi; sekizinci söylemde Zeynep'in nişanlı olduğu kişinin "bir ikinci karısı (hatta bir üçüncü olduğu da söyleniyordu)" olması, Zeynep'in bunu bilmesine rağmen "babasından ve ağabeylerinden korktuğu için evliliğe karşı çıka[maması]"; on üçüncü söylemdeki erkek karakterin "iki karısı[nın] birden" olması gibi örnekler bir erkeğin aynı anda birden fazla kadınla evli olabilmesinin toplum tarafından kanıksanmış bir durum olduğunu, ancak buna dair romanda bir gösterge olmaması nedeniyle kadının böyle bir hakkının olmadığını, ayrıca kadının kimin kaçıncı karısı olacağına kendinin karar veremediğini ve erkekler tarafından tasarlandığı şekilde evlenmelerinin toplum tarafından uygun görüldüğünü göstermektedir. Onuncu söylemde ise "padişah kızlarıyla, sultanlarla evlenen damatların onların üzerine ikinci bir kadın alamama kuralı” bahsedilirken kadınlar üzerindeki baskının her kadında aynı olmadığı, belli bir statüdeki kadınlar üzerinde baskının “öteki” kadınlara göre nispeten yumuşak olduğu görülmektedir. Bu durum yine toplumsal inşa edilmiş cinsiyet beklentileriyle açıklanabilir zira çalışmamızda şu ana kadar çözümlenen söylemlerde Osmanlı hanedanlığına "ait” bir kadının bir öneme sahip olmadığı bulunmuştur. Hanedanlığa "ait" kadınlarla evlenerek Osmanlı yönetim soyuna sonradan dahil olan bir erkek dahi eşinden daha fazla imtiyaza sahip olarak karşımıza çıkmaktadır (Doktor Damat örneği). Osmanlı'da yönetici soya "ait" bir kadının üstüne ikinci bir eş getirilmemesi kuralı, bu kadını hiyerarşik olarak halktan kadınlardan daha üstte gösterirken yine de bu kadın erkeklere nazaran "ikincil” ve öteki" konumuna devam etmektedir.

Tablo 7'de üçüncü söylemdeki “[hepsi erkek olan] memurların şehirden ayrılırken” ve on beşinci söylemde Damat Doktor'un "boş ol” diyerek evliliğe son verebilme haklarının olması, evliliklerinin başlaması üzerinde karar hakkı olmayan kadınların evliliğin ne zaman ve nasıl biteceğine dair karar haklarının da olmadığını göstermektedir. Hem evlilikte hem de boşanmada tek karar verici erkeklerdir ve kadınların her iki durumda da sadece "kabullenen" rolünü oynaması beklenmektedir. Dördüncü söylemde ise Minger Adası'na gelen bir doktorun "adadan bir kız bulup everselerdi, kal[abilecek]" olması, kadının toplumsal rolünün bir erkeğin amaçlarına hizmet etmekten ibaret olduğunu göz önüne sermektedir. Zaten kiminle evleneceği konusunda söz hakkı olmayan kadından, toplumun iyiliği için belki hiç tanımadığı veya görmediği bir doktorla evlilik yapması beklenmektedir. On birinci söylemde Zeynep'i beğenen Kolağası'nın annesine "[b]ana onu al!" diyebilecek bir söylem üretme arzusu, beğendiği kadına bir söz hakkı bırakmamakla birlikte kadını yine evinden edilen bir karakter olarak karşımıza çıkarmaktadır. Evlilikte erkek, evinde sabit kalan tarafken kadın kendi evini terk edip erkeğin uygun gördüğü evde yaşamaya başlamak zorunda olarak görülmektedir.

Yedinci söylemde "Zeynep'in gardiyan babası[nın] Ramiz ile mal mülk pazarlığını yapmış” olması ve on ikinci söylemdeki “Kolağası'nın vereceği başlık parası, hediye, altın gibi konularda anlaşmış” olmaları zaten istekli veya istekli olmadan biriyle ataerkil normlar sebebiyle evlenmek zorunda kalan kadının evden

Adres | Address

RumeliDE Dil ve Edebiyat Araştırmalar Dergisi $\quad$ RumeliDE Journal of Language and Literature Studies

Osmanağa Mahallesi, Mürver Çiçeği Sokak, No:14/8 $\quad$ Osmanağa Mahallesi, Mürver Çiçeği Sokak, No:14/8

Kadıköy - ISTANBUL / TÜRKIYE 34714 Kadıköy - ISTANBUL / TURKEY 34714

e-posta: editor@rumelide.com e-mail: editor@rumelide.com

tel: +90 505 7958124, +90 2167730616 phone: +90 505 7958124, +90 2167730616 
satılan bir eşya gibi objeleştirildiğini işaret etmektedir. Üstelik yedinci söylemde kızının değerini kendisi belirleyen babanın "paranın bir kısmını alıp hemen iki oğluna vermiş" olması ve gösterge yokluğu nedeniyle kızına bu paradan hiç vermemiş olduğu çıkarımının yapılabilmesi de kadının evdeki erkeklerin ortak malı olduğunu ve ekonomik hakkı da olmadığı için kendisi deyim yerindeyse "satın alan" erkeğe karşı daha en baştan bağımlı duruma geldiğini düşündürmektedir. Bu yoruma istinaden, on dördüncü söylemde geçen komutanın "karısı sözünü dinlemeyince ne yapacağını hiç bilem[emesi], odayı terk ediyor [olması] ve öfkesinin geçmesini bekl[emesi]", bir eşya gibi erkeğe satılan kadından beklenen tek rolün erkeğin "sözüne itaat etmesi" olduğunu, aksi durumun ise toplumsal cinsiyet normları dışında olduğunu ve erkeğin böyle bir duruma karşı çok öfkelenebildiğini göstermektedir. Bahsedilen bu normların dışındaki kadın, hem aile içinde hem de toplumsal olarak "öteki” konumuna yerleştirilmektedir.

Dokuzuncu söylemde, genel toplumsal cinsiyet beklentisi olan namusun kadına yıkılması durumu söz konusudur. "[K]ızının ancak adadan kaçarak ailesinin ve kendisinin şerefini kurtarabilecek" olması, tüm bu cinsiyet adaletsizliği içinde erkeğin kendi hayatına devam ederken kadının namus "objesi" olarak yerini yurdunu terk etmesi gerektiğini göstermektedir. Kadın ve erkeğin medeni durumun her bir evresinde eşit olabildiği bir toplumda, "namus" olgusu bir cezalandırma durumuna dönüşmeyip sadece kadına da yıkılamayacaktır. Nişanlısını istemeyerek medeni durumda salt "kabullenen" olmayan bir kadının namus yoksunluğu ile suçlandığı ataerkil yapıda kadına karşı işlenen her türlü şiddet doğal görülür hale gelmektedir. Son olarak, Vali Sami Paşa ve sevgilisi Marika arasındaki bir diyalogdan kurulu olan altıncı söylemde Marika'nın Vali Sami Paşa'ya "siz" diye hitap ederken Sami Paşa'nın Marika'ya "sen" diye hitap ediyor olması statü saygınlığı ile açıklanamaz zira iki sevgili arasında statü farkının bir hiyerarşi oluşturması düşünülemez. Bu söylemdeki hitap farkının kadın-erkek eşitsizliğinden kaynaklandığı düşünülebilir. Vilayetteki iktidar sahibi Sami Paşa sevgilisi Marika'nın evine sadece diğer işlerinden arda kalan zamanda gider. Marika hep evde bekleyen konumunda iken Sami Paşa görüşme zamanlarına karar veren taraftır. Bu ilişkide de sahip olduğu meslek sebebiyle (öğretmenlik) romandaki diğer kadın karakterlerden ayrılabilen Marika yine hem görüşme zamanları hem de evlenip evlenmeyecekleri konusunda erkeğin kararını kabullenen taraftır.

\subsection{Romanda eril dil kullanımı}

Şu ana kadar çözümlenen tüm söylemler, toplumun kadına "birine ait olma", "bir işleve indirgenmiş", "öteki", "erkeklerin verdiği kararlara boyun eğen", "eve hapsedilmiș" ve "evlilikte kabullenen" rolünü biçtiğini göstermektedir. Ataerkil toplum yapısının kadınlara uygun gördüğü bu "ikincil” ve "göz ardı edilen" etiketleri, yazınsal metnin dilinde de eril bir dil kullanılmasının önünü açmıştır. Türkçe her ne kadar Avrupa dilleri kadar cinsiyetçi bir dil olarak görülmese de romanda eril dil kullanımına dair örnekler saptanmış ve Tablo 8'de verilmiștir.

Tablo 8. Romanda eril dil kullanımı saptanan söylemler4

1. “Böylece Osmanlı'ya 'hasta adam' diyenlere de güzel bir cevap vermiş oldunuz [...]” (Pamuk, 2021, s. 20)

2. İmparatorluk bürokrasisinde ve sağlık teşkilatında bir çeşit "kurtarıcı ilim adamı" olarak da tanınıyorlardı. (Pamuk, 2021, s. 36)

3. Konsolosların da teşvikiyle bu adayı Girit gibi oldu bittiye getirip bizden koparmak isteyen çok adam vardır Paşam. (Pamuk, 2021, ss. 38-39)

4. Merak etmeyiniz, gittiğiniz her ev, her bina valilik mensupları, satıcı kılı̆̆ındaki casuslar ve başka adamlarımız tarafından çok yakın bir gözetim altında olacaktır. (Pamuk, 2021, ss. 42-43)

Tablo 8'deki eril dil kullanımına ait göstergeler bu çalışmanın yazarı tarafından vurgulama amacıyla eğik yazıyla yazılmıștır. Adres | Address

RumeliDE Dil ve Edebiyat Araştırmaları Dergisi $\quad$ RumeliDE Journal of Language and Literature Studies Osmanağa Mahallesi, Mürver Çiçeği Sokak, No:14/8 $\quad$ Osmanağa Mahallesi, Mürver Çiçeği Sokak, No:14/8 Kadıköy - ISTANBUL / TURKIYE 34714 Kadıköy - ISTANBUL / TURKEY 34714 e-posta: editor@rumelide.com e-mail: editor@rumelide.com tel: +90 505 7958124, +90 2167730616 phone: +90 505 7958124, +90 2167730616 
5. Az sonra her yere adam yollayıp onu mutlaka bulurlardı. (Pamuk, 2021, s. 61)

6. [...] bu adada insanoğlunun yaşadığını, çalıştığını ve savaşıp birbirlerini öldürdüğünü hatırlıyordu. (Pamuk, 2021, s. 74)

7. Karantina teşkilatı da sorunun bir parçası haline gelmiști. Vilayet müdürlüklerine katipler, muhafızlar, hademeler için pek çok kadro açılıyor, adam alınıyor [...] (Pamuk, 2021, s. 91)

8. [...] taahhütlü posta daha pahalı ve dağıtım çok vakit aldığı için herkes Postane’ye adamını yollardı. (Pamuk, 2021, s. 111)

9. Vali Pașa, tanıdığı pek çok bürokrat ve devlet adamı gibi heyet üyelerinin de bir şeyi yasaklamaktan mutluluk duyduklarını hissettiği için bir an kaşlarını kaldırdı. (Pamuk, 2021, s. 116)

10. [...] Osmanlı'nın tahaffuzhane dediği karantinahanelere, tecrit odalarına ve babadan kalma korunma yollarına başvurmaya zorlamıştı. (Pamuk, 2021, ss. 117-118)

11. Vali, çevresine hemen topladığı katibi ve adamlarına karantina kararlarını gazetelere şimdilik vermemelerini söyledi. (Pamuk, 2021, s. 121)

12. Zarar ziyan komitesinin adamları (defterdarlı memurları), malların toplanması, dükkanların baştan aşağı boşaltılıp kireçlenmesi sırasında bazan bol keseden tazminat vaadi yazdıkları için kimi dükkanlarda hiç sorun çıkmadı. (Pamuk, 2021, s. 136)

13. "Bonkowski Paşa yalnızca adam asmak, dayak atmak ve zindana adam tıkmanın ne karantinaya ne de modern ve Avrupai olmaya yeteceğini hep söylemiştir." (Pamuk, 2021, s. 147)

14. "[...] İçimizden birinin başına bir şey gelirse bunun da o Ramiz ve adamlarının elinden çıkacağına da eminim." (Pamuk, 2021, s. 147)

15. Theodoropulos Hastanesi'nin bahçesinde sabah bulunan bir ölüyü ve Petalis'te bir lokantanın Rum garsonunun ölümünü adamlarından işitmişti. (Pamuk, 2021, s. 177)

16. [...] fare zehriyle tarçını aynı anda satan ve macun ve hap hazırlayan babadan kalma aktarlardı. (Pamuk, 2021, s. 204)

17. Korkudan işe gelmeyen memur sayısı arttıkça Sami Paşa'nın adamlarının Ramiz'i şehrin içinde takip etmeleri de zorlaşıyordu. (Pamuk, 2021, s. 302)

18. Kendisinin ve adamlarının Padişah hazretlerinin buyurdukları gibi İbrahim Hakkı Paşa'yı Minger'in yeni valisi olarak tanıdığını ve yarın valilik koltuğuna onu oturtacağını söyledi. (Pamuk, 2021, s. 303)

19. [...] Ramiz ve yeni valinin adamları [...] (Pamuk, 2021, s. 304)

20. Şeyh Hamdullah'ın yanında en sadık adamı keçe külahlı derviş Nimetullah Efendi'yi gördü. (Pamuk, 2021, s. 312)

21. [...] toplantı salonunun girişlerinde ve içerisinde Vali'nin, silahlı on sekiz adamı vardı. Bunların bazılarını silahlarını açıkça taşıyan muhafızlardı. Bazıları da memur, uşak, dükkan sahibi kıyafet ve kisvesiyle salona gelmiş silahlı adamlardı. (Pamuk, 2021, s. 317)

22. “[...] karantina idaresi ve devlet de adil bir baba gibi kardeşlere eşit mesafede olmalı." (Pamuk, 2021, s. 341)

23. Değil İngiliz ya da Fransız, sıradan bir korsan gemisi, adanın kuzey sahillerine iki yüz silahlı adam çıkarsa [...] (Pamuk, 2021, s. 358)

24. Ramiz ve adamları inandıkları dava için gözlerini kırpmadan adam öldürebilecek -hele Hıristiyan olunca-, bu konuyu ahlaki bir mesele haline getiremeyecek bir rahatlık içindeydiler. Kuzey dağlarında çok köy basmış, yağmalamış ve çok adam öldürmüşlerdi. (Pamuk, 2021, s. 358)

25. Daha Arkaz şehri bile kurulmamışken körfez açıklarındaki kayalıklara bindiren tekneden inen kişiler bugünkü Mingerlilerin dedeleriydiler. Onlar bu adayı çok sevmişler, onun kayalıklarını, pınarlarını, ormanlarını ve denizini kendilerine ev olarak benimsemişlerdi. (Pamuk, 2021, s. 402)

26. Sami Paşa çatışmadan sonra [...] iki saat Marika'da saklanmış ama [...] fazla durmadan adamlarının rehberliğinde arka sokaklardan şehir dışına kaçmıştı. (Pamuk, 2021, s. 413)

27. Ali Talip'in adamları bu polislere hiç karşı koymamıştı. (Pamuk, 2021, s. 414)

Adres | Address

RumeliDE Dil ve Edebiyat Araştırmaları Dergisi Osmanağa Mahallesi, Mürver Çiçeği Sokak, No:14/8 Kadıköy - İSTANBUL / TÜRKIYE 34714 e-posta: editor@rumelide.com tel: +90 $5057958124,+902167730616$
RumeliDE Journal of Language and Literature Studies

Osmanağa Mahallesi, Mürver Çiçeği Sokak, No:14/8

Kadıköy - ISTANBUL / TURKEY 34714

e-mail: editor@rumelide.com

phone: +90 5057958124 , +90 2167730616 
28. Hacı Gemisi İsyanı'na karıșan ve Ramiz ve adamlarının ortak hareket ettiği Nebiler ve Çifteler köylüleri [...] (Pamuk, 2021, s. 415)

29. Nikiforo’yu babadan kalma yöntemlerle falakaya yatırılan ve işkenceden geçirilenlerin itirafları ipe götürmüştü. (Pamuk, 2021, s. 424)

30. Tecavüz, kız kaçırma, mala el koyma, adam öldürme gibi başka, daha ağır suçlar da işlenmişti iddialara göre [...] (Pamuk, 2021, s. 436)

31. Herkes tarafından sevilen Hamdi Baba da bunlardan biriydi. Beraat eder etmez Arkaz'a iki saat uzaklıktaki servili ve kayalık köydeki baba evine dönmüştü. (Pamuk, 2021, s. 461)

Tablo 8'de görülebileceği üzere üçüncü, dördüncü, sekizinci, on birinci, on ikinci, on dördüncü, on beşinci, on yedinci, on sekizinci, on dokuzuncu, yirminci, yirmi birinci, yirmi üçüncü, yirminci dördüncü, yirmi altıncı, yirmi yedinci ve yirmi sekizinci söylemlerde "birinin yanında çalışan" ifadesi "adam(ları)" göstergesi ile verilmiştir. Türk Dil Kurumu çevrimiçi sözlükte "adam" göstergesinin tanımları içinde "birinin yanında bulunan ve işini yapan kimse", "birinin yararlandığı, kullandığı kimse" ve "daima birinin yanında olan, onu destekleyen, isteklerini yerine getiren kimse" 5 geçmektedir. Belirtilen söylemlerde bu üç tanıma da uyan "adam" göstergesinin, eril tahakkümün öne çıktığı bir eserde kullanılmış olması eserin yazınsal feminist çözümlemeye uygunluğunu göstermektedir. Bu söylemlerde "yanında çalışan(lar)" veya "kişi(ler)" göstergelerinin kullanılması eril dil kullanımını yok edebilecekken yazarın romanın Giriş bölümünde de açıkça belirttiği üzere toplumsal inşaya dayalı cinsiyet rollerinin getirdiği adaletsizliği pekiştirmek için yazarın bu dil tercihinde bulunduğu düşünülebilir. Ayrıca bu durum, toplumda yönetici kesimdekilerin, çalışanların ve dışarıda olanların sadece erkeklerden oluştuğunu perçinlemektedir. "Adam" göstergesinin eril dil tercihi amacıyla kullanılması sonucu ikinci söylemde "ilim adamı", beşinci söylemde "adam yollamak", yedinci söylemde "adam almak", dokuzuncu söylemde "devlet adamı", on üçüncü söylemde "adam asmak" ve "adam tıkmak", yirmi dördüncü ve otuzuncu söylemlerde "adam öldürmek" ifadeleri karşımıza çıkmaktadır. Ataerkil toplum yapısında aktif bir işin genelde erkekler tarafından yapılması kabul edildiği için bazı deyimsel ifadeler ve meslek adları da eril dile tabi olmuştur. Bu söylemlerin tümünde "insan" göstergesi kullanılıp eril dil yok edebilecekken yazarın romandaki ataerkil toplum değerlerini dile yerleșmiş olan eril göstergeye dayalı deyimsel ifadeler ve meslek adları ile verdiği görülmektedir. Birinci söylemde, çöküş dönemindeki Osmanlı için Avrupa'nın kullandığı "Sick man of Europe" göstergesi "hasta adam" göstergesi ile karşımıza çıkmaktadır. Cinsiyetçi diller arasında olan İngilizcede kullanılan "man" gibi Türkçede de kullanılan "adam", bir ülkeyi tanımlamak için kullanılmış bir eril dil göstergeleridir. Bunun yanı sıra, altıncı söylemde tüm insanlara atıf yapmak için kullanılan "insanoğlu" göstergesi de içindeki "oğlu" kelimesi nedeniyle eril dil kullanımına örnek gösterilebilir. Her ne kadar son ylllarda özellikle akademik alanda bu gösterge yerine "insan" tercih edilmekte olsa da İngilizcedeki gibi tüm insanlara atıf yapmak için "erkek, adam" anlamına gelen "man" göstergesi gibi "insanoğlu" kelimesi yazınsal metinlerde karşımıza çlkabilmektedir.

Onuncu, on altıncı ve yirmi dokuzuncu söylemlerdeki "babadan kalma", yirmi ikinci söylemde devleti nitelemek için kullanılan "baba", yirmi beşinci söylemde Minger'e ilk yerleşenlere atıfta bulunmak için kullanılan "bugünkü Mingerlilerin dedeleri" ve otuz birinci söylemde kullanılan "baba evi" göstergeleri, insanların kendilerinden önceki aile büyüklerine veya devlet büyüklerine atıf yapmak için eril göstergeleri tercih ettiğini, ayrıca sahip oldukları malların veya mesleklerin eski sahiplerinin yine erkekler (babalar) olduğunu, kadınların herhangi bir güce ve mal mülke sahip olamadığını ima etmektedir. Böylece, romandaki eril dil tercihinin romanın bütünündeki erkek egemen toplumu pekiştirmek için kullanıldığı düşünülse de

Türk Dil Kurumu. Güncel Türkçe Sözlük. https://sozluk.gov.tr/. [Erişim Tarihi: 25.07.2021]

Adres Address

RumeliDE Dil ve Edebiyat Araşttrmaları Dergisi $\quad$ RumeliDE Journal of Language and Literature Studies

Osmanağa Mahallesi, Mürver Cicceği Sokak, No:14/8 Osmanağa Mahallesi, Mürver Çiçĕ̌i Sokak, No:14/8

Kadıköy - İSTANBUL / TÜRKIYY 34714 Kadıköy - ISTANBUL / TURKEY 34714

e-posta: editor@rumelide.com e-mail: editor@rumelide.com

tel: +90 505 7958124, +90 216773 o 616 phone: +90 505 7958124, +90 2167730616 
toplumsal cinsiyet rollerinin yazınsal eserlerde yeniden üretilmemesi için eril dil kullanımından kaçınabilmenin de mümkün olduğu gösterilmiştir.

\section{Sonuç ve romanın gelecekteki çevirileri için feminist değerlendirme}

Veba Geceleri romanının henüz herhangi bir dile çevirisi bulunmamakla birlikte eserleri en çok çevrilen Türk roman yazarları arasında olan Orhan Pamuk'un bu romanının da çok sayıda dile hatta belki defalarca çevrileceği beklenmektedir. Özellikle günümüzde tüm dünyanın içinde bulunduğu salgın şartlarının bu romanın farklı dillere çevirilerini daha da hızlandıracağı düşünülebilir.

Romanın gelecekte göstergelerarası bir çeviriyle bir dizi film olarak yayınlanması durumunda romandaki eril tahakkümün ve toplumsal cinsiyet rollerinin toplumda yeniden üretileceği açıktır. Her ne kadar tarihi bir roman olup bir asırdan daha önceki bir zamandaki kadının toplumdaki [olmayan] yerini ele alan bir eser olsa da özellikle dizi film gibi bir yapımla daha geniş bir kitleye ulaştığında bu rollerin yeniden üretilmesi kaçınılmaz bir durum olabilir. Bu durum, romanın göstergelerarası çeviri yapılmasına karşı çıkmamaktadır, tam aksine böyle bir çeviri yapılacaksa Orhan Pamuk'un bu romandaki kadın karakterlere dair "feminist eleştirileri de haksız bulmuyorum" 6 açılamasında belirttiği gibi toplumsal cinsiyet rollerinin yeniden üretilmemesi için senaryonun feminist eleştiriden geçirilmesi önerilmektedir.

Romanın yapılacak dillerarası çevirileri öncesi feminist okuma ekseninin çözümlenmesi önem arz etmektedir. Her ne kadar çoğu meslek sahibi erkekler olarak ifşa edilse de romanda cinsiyeti verilmeden kullanılan "asker, çevirmen, bürokrat, memur, uşak, itfaiyeci, manav, doktor, tüccar" gibi mesleklerin özellikle batı dillerine yapılacak çevirilerde eril ve dişil artikellerden veya atıf amaçlı zamirlerden hangisinin kullanılacağı ancak romanın feminist okuma ekseni ile çözülebilecek sorulardır. Toplumsal cinsiyet inşasında olduğu gibi bu mesleklerin erkeklere ait meslekler olarak yorumlanıp sadece eril artikeller veya zamirler kullanılarak çevrilmesi yerine çevirmenlerin bilinçli çeviri tercihleri yapabilmeleri feminist okuma eksenine bağlıdır.

Ayrıca kadınların okura tanıtıldığı söylemlerde yazarın, Türkçenin de mümkün kıldığı biçimde öncelikle kadının hangi erkeğe hangi bağla "ait olduğunu" daha sonra ise kadının adını bilinçli bir şekilde aktardığı (bkz. Tablo 2) düşünüldüğünde özellikle Avrupa dillerinde bu göstergelerin kadının "ait olma" durumunu öne çıkararak çevirisi için bilinçli çeviri tercihleri yapılmalıdır. Örneğin, "Abdülhamit'in yeğeni Pakize Sultan" söylemi İngilizce "Pakize Sultan, Abdulhamit's niece" veya "Abdulhamit's niece, Pakize Sultan" göstergelerinin her ikisiyle de çevrilebilirken kadının "aitlik" durumu ikinci çeviride daha belirgin olacaktır. Bu noktada çevirmenin skoposu ve ideolojik yaklaşımı da önem arz etmektedir. Toplumsal cinsiyet rollerini diğer bir kültüre özgün kültürde olduğu gibi aktarmak isteyen çevirmen bu cinsiyet rollerini yeniden üretecek tercihlerde bulunacakken, toplumsal cinsiyet rollerini yıkmak isteyen bir çevirmen erek kültüre kadınları sadece kendi adlarıyla ve bağımsız bireyler olarak çevirmeyi de tercih edebilir. Bu ikinci durum, romanın içeriğine, odak noktasına, özgün kültürün sosyolojik yapısına ve tarihine dolaysız bir müdahale olacakken aynı zamanda toplumun inşa ettiği cinsiyet rollerine de geç kalınmış bir müdahale olarak karşımıza çıkabilir.

Çözümlemede ortaya çıan "kadınların bir işleve indirgenmesi" durumuna ait göstergeleri ve söylemleri, feminist okuma yapmaksızın çevirmenin yakalayabilmesi mümkün olmayabilir. Bir üst paragrafta belirtilen

6 Devrim Beyaz. (30 Mayıs 2021). Orhan Pamuk: “Feminist Eleştirmenle Kavga Eden Orta Doğulu Erkek Yazar Her Zaman Haksızdı". https://kayiprihtim.com/haberler/edebiyat/orhan-pamuk-veba-geceleri-kadin-karakterler/. [Erişim Tarihi: 25.07.2021].

RumeliDE Dil ve Edebiyat Araşturmaları Dergisi Osmanağa Mahallesi, Mürver Çiçeği Sokak, No:14/8 Kadıköy - İSTANBUL / TÜRKIYE 34714 e-posta: editor@rumelide.com tel: +90 $5057958124,+902167730616$

Address

RumeliDE Journal of Language and Literature Studies

Osmanağa Mahallesi, Mürver Çiçeği Sokak, No:14/8

Kadıköy - ISTANBUL / TURKEY 34714

e-mail: editor@rumelide.com

phone: +90 505 7958124, +90 2167730616 
çevirmenin skoposunun tutarlılığı amacıyla bu göstergelerin yakalanması gerekmektedir. Toplumsal cinsiyet rollerini yıkmak isteyen bir çevirmen bu söylemlerde kadınları "dedikodu ve dış görünüş merakı" ile sınırlandırılan işlevlerden kurtararak romanın başka bölümlerindeki söylemlerde kadınların her bir başarısını (her ne kadar romanda ender durumlar olsa da) takdir edilmeye layık olarak çevirmeye yönelik çeviri tercihleri kullanabilir. Ancak özgün metne tamamıyla sadık kalarak çevirisini yapacak olan çevirmen için bu işleve indirme göstergelerinin erek kültüre aktarımında özgün ve erek kültürler arasındaki kadının konumu farkının ne düzeyde aşllabileceği sorununu gidermek önemli bir mesele olacaktır.

Sadece erkeğin yapmasının uygun görüldüğü davranışların kadınlar tarafından sergilenmemesi beklentisi sonucunda "ötekileștirilen" kadınlara dair söylemlerde, iktidarın salt erkeğin elinde olduğu söylemlerde ve kadına biçilen toplumsal uzamın "ev" ile kısıtlandığı söylemlerde çok sayıda özgün kültüre özgü ögeler yer almaktadır. Bu ögeler (kıyafetler, yer adları, meslek adları, dini ritüeller, lakaplar, özel adlar, günlük rutin işler, siyasi arkaik göstergeler) kadının ötekileştirilmesine, sadece yönetilen konumunda olmasına ve ev uzamıyla kısıtlanmasına dair açık veya örtük göstergeler olarak karşımıza çıkmaktadır. İktidarın salt erkeklere ait görülmesi hemen hemen tüm toplumlarda karşımıza çıkmaktadır ve bu uygulamayı sonlandırmak için tüm çabalara rağmen ataerkil toplum bunu devam ettirmektedir. Burnier (2003, s. 37), feminist yaklaşımlar sayesinde Batı'da (Amerikan toplumu özelinde) kadınların yönetimde yavaş da olsa yer almaya başladığını lakin bunun hem nicelik hem de nitelik olarak daha fazla feminist çalışma ile görünür kılınması gerektiğini ifade ederken üst düzey yönetimin halen erkeklerin elinde olduğunu belirtmektedir. Brines (1994, s. 652-653), kadına biçilen toplumsal uzamın ev olmasının ve çocuk bakımı dahil tüm ev işlerinin toplumsal bellekte kadına bırakılmasının nedeninin kadınların ekonomik olarak çoğunlukla dışarıda çalışan eşlerine bağımlı olmasından ve toplumsal kadınlık-erkeklik beklentilerinden kaynaklandığı sonucuna varmıştır. Benzer şekilde Kroska (1997, s. 310), toplumsal kadın rolleri olarak görülen kadınların ev işlerini yaparak erkeklerinse toplum belleğindeki dışarıda çalışarak para getiren bireyler olarak toplumsal beklentiyi karşılamak amacıyla kadınların eve uygun görüldüğünü, bunun doğanın getirdiği bir süreç olmadığını, tam olarak toplumsal cinsiyet rolleri inşasından kaynaklandığını ifade etmektedir. Görüldüğü üzere kadına biçilen toplumsal uzamın ev olması kültürlerarası bir ataerkil toplum uygulamasıdır. Erek kültürün özgün metne yakın veya uzak olmasına bakmaksızın bu kültüre özgü ögelerin kadın ve erkek rollerine dair erek kültürde karşılıkları bulunmaması durumunda çevirmenlerin yine skoposlarına göre çeviri stratejileri kullanmaları gereklidir. Açımlanan kültürel ögeler toplumsal cinsiyet rollerini tekrar üretecekken erek metinden silinen veya erek kültüre yerlileștirme stratejileri ile çevrilecek olan ögeler sonucunda özgün metinde baskın bir tema olan toplumsal cinsiyet rollerinin şiddeti azalacak veya artırılacaktır. Bu konuda feminist kuramların, özellikle yazınsal feminizmlerin çevirmenin skoposunu belirlemesinde yardımcı olacak daha köklü adımlar atması gerekmektedir. Yazınsal metinlerde sürekli karşılaştığımız kadının baskılanması veya ötekileștirilmesinin çeviri metinlerde sürdürülmesi ve topluma bu adaletsizliği yeniden gösterilmesi mi gerektiği yoksa artık bu baskılanma ve ötekileştirmeleri yeterince çözümlenmiş sayıp çeviri metinde var olan toplumsal cinsiyet rollerinin yıkılarak erkekle eşit bir kadının veya kadınların çevirisi mi yapılacağı yönünde tartışmalar elzemdir.

Medeni durumda kadına salt kabullenen rolü verilen söylemlerdeki "Boş ol" göstergesi yan anlam ve kültürel alt yapı olarak günümüz özgün kültür toplumunda olmadığı gibi çevirisi yapılacak potansiyel Batı dillerinde de bulunmamaktadır. Bunun yanı sıra, kadın erkeğe "siz" diye hitap ettiği erkeğin ise kadına "sen" diye hitap ettiği söylemler Fransızca (tu-vous) ve Almanca (du-Sie) dillerinde karşıllğı bulunuyorken İngilizcede her ikisi de "you" zamiri ile karşılanmaktadır. Bu durumda İngilizcenin sınırları zorlanarak veya bazı açımlamalarla bu fark İngiliz kültürüne de taşınabilir. Açımlama ile birlikte kadının medeni kanunda salt "kabullenen" rolü daha da şiddetli bir biçimde metne yansıyacaktır ve bu rolü yeniden üretecektir. İngilizcenin sınırlarını zorlamadan veya açımlama yapmaksızın çevrilecek bu söylem ise metnin feminist

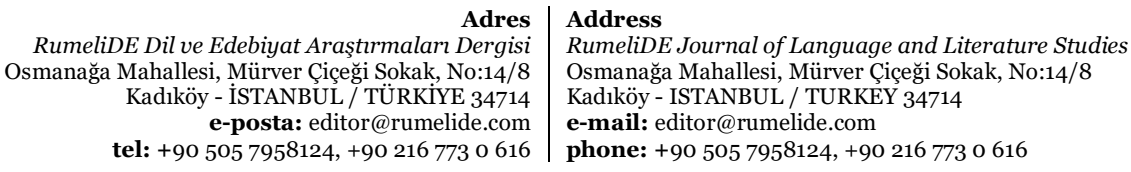


okumasında büyük değişikliklere neden olacaktır. Son olarak, polijini bazı kültürlerde ender görülse de halen var olan bir toplumsal uygulama olmasına rağmen modern dünyada, özellikle Batı kültüründe kabul edilmeyen bir durumdur. Günümüz özgün metin kültüründe polijini medeni kanun hükümlerince yasaklanmış bir uygulamadır. Lakin özgün metin okuru tarihsel ve kültürel bagajıyla kadının bu kabullenmiş olma rolünü alımlayabilmesine rağmen Batı okuru için alımlanabilen bir gösterge olmayabilir. Bu durumda çevirmenin ek bilgi ile bu göstergeleri Batı okuruna taşıması özgün metnin öykü zamanında doğal karşılanan bir olguyu daha şiddetli bir biçimde alımlamasına neden olacaktır. Çevirmenin skoposuna göre bu göstergelerin silinmesi tercihi alındığında ise metnin anlam evreni erek metinde kaybolacaktır.

Kadını "ikincil" varlıklar olarak gösteren veya yok sayan tüm bu özgün metin göstergeleri sonrası metinde yoğun bir biçimde saptanan eril dil kullanımı, cinsiyetçi diller olarak görülen Batı dillerinde daha şiddetli bir biçimde okura yansıtılabilir. Fakat bu durum, kullanılan deyimlerde eril tahakkümü yeniden üretecektir. "Kullandığımız cinsiyetçi sözcükler var olan durumu daha da güçlendirirler [...] Mevcut durumu devam ettirmek veya yeni gerçeklikler inşa etmek için farklı düşünce tarzlarını ortaya çıkarmak amacıyla kullandığımız sözcükleri seçebiliriz" (Kleinman, 2002, s. 300). Özellikle yazında seçilen sözcükler ve söylemler eril dil kullanımını görünür hale getirmektedir. Bu durum şüphesiz metnin çevirilerine de yansıyacaktır. Doyle'a (1998, s. 149) göre, cinsiyetçi dil kullanımı kadınlara ayrımcllı yapan veya onları yok sayan, erkekliği doğal gösterip kadınlığı standart dışı bir biçimde gösteren dil kullanımıdır. Görüldüğü gibi, cinsiyetçi dil kullanımı sadece kadınları ötekileștiren ve erkek egemenliğini sürdüren bir uygulamadır. İngilizcede "adam öldürmek" gibi içinde "adam" geçen deyimsel ifadeler belgisiz zamir olan "someone" göstergesi ile cinsiyet bakımından nötr bir ifade ile karşılanabilir. Bunun yanı sıra, Almanca ve Fransızca gibi dillerde "adam" göstergesinin yerine "insan" anlamına gelen nötr göstergeler tercih edilerek eril dil kullanımından kaçınılabilir. Ayrıca "babadan kalma" gibi göstergeler Batı kültüründe daha çok "ailesinden kalma" anlamına gelecek göstergelerle karşılandığı için bu eril niteleme ifadesi toplumsal cinsiyet bakımından nötr göstergelerle karşılanabilir. Karşıllanamadı̆̆ı durumda çevirmenlerin, toplumsal cinsiyet rollerini tekrar üretmemek için erek dilin şartlarını zorlaması önerilmektedir. Ancak çevirmenin skoposu eril dil kullanımını erek kültüre yansıtarak ataerkil yapıyı ve dile yansımaları üzerine bilinç uyandırmak olacaksa Batı dillerinin buna müsait olduğu açıktır.

Sonuç olarak bu çalışmada, feminist yazın kuramının çevirmenlere skopos önermede daha aktif olması önerilmektedir. Günümüz çeviribilim çalışmalarında özellikle feminist kuramın çeviribilime uygulanmasından itibaren çevirmen özgün metne totaliter bir sadakat ile çeviri yapma edimiyle kısıtlanmaması nedeniyle edindiği skoposa göre çeviri kararlarını ve tercihlerini yönlendirebilecektir. Feminist yazın kuramından beklenen, ataerkil toplum yapısının yeniden üretildiği yazınsal metinlerin çevirisinde çevirmenin benimseyeceği skopos yelpazenin hangi ucunda olursa olsun erek metnin ataerkiyi yıkacak şekilde üretiminin teșvik edilmesidir.

\section{Kaynakça}

Aydoğdu Çelik, M. (2020). Crossdressing as a strategy in defence of women in Giulia Bigolina's Urania. Tuna, D., Kuleli, M. ve Aliyev, J. (Eds.), Yazınsal feminizmler: Yöndeşimler ve Kesişimler içinde (ss. 139-160). Ankara: Nobel Bilimsel Eserler.

Bălan, A. (2020). French women as the other in some Victorian novels. Translation Studies: Retrospective and Prospective Views, 23, 19-28.

Beyaz, D. (30 Mayıs 2021). Orhan Pamuk: “Feminist Eleştirmenle Kavga Eden Orta Doğulu Erkek Yazar Her Zaman Haksızdır". https://kayiprihtim.com/haberler/edebiyat/orhan-pamuk-veba-geceleri-kadinkarakterler/. [Erişim Tarihi: 25.07.2021].

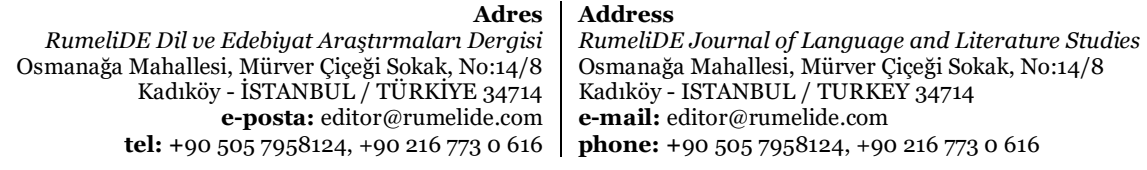

Adres
RumeliDE Dil ve Edebiyat Araşturmaları Dergisi tel: +90 $5057958124,+902167730616$ 
Black, P., ve Sharma, U. (2001). Men are real, women are 'made up': Beauty therapy and the construction of femininity. The Sociological Review, 49(1), 100-116.

Brines, J. (1994). Economic dependency, gender, and the division of labor at home. American Journal of Sociology, 100(3), 652-688.

Burnier, D. (2003). Finding a voice: Gender and subjectivity in public administration research and writing. Administrative Theory \& Praxis, 25(1), 37-60.

De Beauvoir, S. (1949). The second sex. London: Four Square Books.

Doyle, M. (1998). Introduction to the A-Z of non-sexist language. D. Cameron (ed.), The feminist critique of language: A reader içinde, (ss. 149-154). (2. Baskı). London and New York: Routledge.

Greene, G., ve Kahn, C. (1985). Feminist scholarship and the social construction of woman. Greene, G. ve Kahn, C. (Eds.) Making a Difference: Feminist Literary Criticism içinde (ss. 1-36). London: Routledge.

Habertürk. (9 Nisan 2021). https://www.haberturk.com/orhan-pamuk-veba-geceleri-ni-anlatti-buromanim-cok-guzel-dizi-olur-3032308. [Erişim Tarihi: 23.07.2021]

Kaplan, S. J. (1985). Feminist scholarship and the social construction of woman. Greene, G. ve Kahn, C. (Eds.) Making a Difference: Feminist Literary Criticism içinde (ss. 37-71). London: Routledge.

Kleinman, S. (2002). Why sexist language matters. Qualitative Sociology, 25(2), 299-304.

Kroska, A. (1997). The division of labor in the home: A review and reconceptualization. Social Psychology Quarterly, 60(4), 304-322.

Lorber, J. (1991). The social construction of gender. Lorber, J. ve Farrell, S. A. (Eds.) Sex and Gender içinde (ss. 111-118). Newbury Park, CA: Sage.

Lorber, J. (1997). The variety of feminisms and their contributions to gender equality. Oldenburg: Bibliotheksund Informationssystem der Universität Oldenburg.

Pamuk, O. (2021). Veba geceleri. İstanbul: Yapı Kredi Yayınları.

Strelan, P., ve Hargreaves, D. (2005). Women who objectify other women: The vicious circle of objectification?. Sex roles, 52(9-10), 707-712.

Tetik, K. (2020). Kutadgu Bilig, Mârifetnâme, Vladimir Monomah’ın Öğretisi ve Domostroy eserlerinde kadın algısı. Tuna, D., Kuleli, M. ve Aliyev, J. (Eds.), Yazınsal feminizmler: Yöndeșimler ve Kesişimler içinde (ss. 89-119). Ankara: Nobel Bilimsel Eserler.

Tuna, D., ve Çelik, C. (2020). Princesses dethroning patriarchy: De/re-constructions and redefinitions in children's literature. Tuna, D., Kuleli, M. ve Aliyev, J. (Eds.), Yazınsal feminizmler: Yöndeşimler ve Kesişimler içinde (ss. 1-32). Ankara: Nobel Bilimsel Eserler.

Tuna, D, Kuleli, M., ve Aliyev, J. (2020). Ön söz. Tuna, D, Kuleli, M., ve Aliyev, J. (Eds.) Yazınsal feminizmler: Yöndeșimler ve Kesişimler içinde (ss. iii - iv). Ankara: Nobel Bilimsel Eserler.

Türk Dil Kurumu. Güncel Türkçe Sözlük. https://sozluk.gov.tr/. [Erişim Tarihi: 25.07.2021]

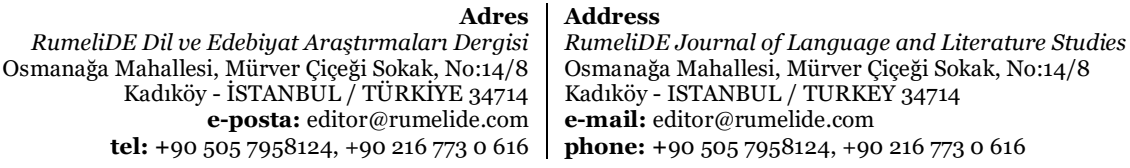

Adres
RumeliDE Dil ve Edebiyat Araşttrmaları Dergisi tel: +90 $5057958124,+902167730616$ 